\title{
RMetS
}

Royal Meteorological Society

\section{Modelling the vertical structure of the atmospheric boundary layer over Arctic fjords in Svalbard}

\author{
T. Kilpeläinen, ${ }^{\mathrm{a}, \mathrm{b} *}$ T. Vihma, ${ }^{\mathrm{c}}$ M. Manninen, ${ }^{\mathrm{d}}$ A. Sjöblom, ${ }^{\mathrm{a}, \mathrm{b}}$ E. Jakobson, ${ }^{\mathrm{e}}$ T. Palo ${ }^{\mathrm{e}}$ \\ and M. Maturilli ${ }^{\mathrm{f}}$ \\ ${ }^{a}$ The University Centre in Svalbard, Longyearbyen, Norway \\ ${ }^{\mathrm{b}}$ Geophysical Institute, University of Bergen, Norway \\ ${ }^{\mathrm{c}}$ Finnish Meteorological Institute, Helsinki, Finland \\ ${ }^{\mathrm{d}}$ University of Helsinki, Finland \\ ${ }^{\mathrm{e}}$ University of Tartu, Estonia \\ ${ }_{\mathrm{f}}$ Alfred Wegener Institute for Polar and Marine Research, Potsdam, Germany
}

${ }^{*}$ Correspondence to: T. Kilpeläinen, Finnish Meteorological Institute, PO Box 503, FI-00101 Helsinki, Finland. E-mail: tiina.kilpelainen@fmi.fi

The vertical structure of the atmospheric boundary layer (ABL), simulated with the mesoscale model Weather Research and Forecasting (WRF) as well as with its polar optimized version Polar WRF, was compared to tethered balloon soundings and mast observations taken in March and April 2009 from two Arctic fjords in Svalbard. From twelve short $(48 \mathrm{~h})$ simulations, the Quasi-Normal Scale Elimination scheme for the ABL and the NOAH land surface scheme for the surface were found to perform best and were selected for one long (16 day) simulation. The differences in performance of the standard WRF and Polar WRF were marginal. A warm bias, especially near the surface, was found in the modelled temperature profiles related to underestimated temperature inversion strength and depth. The modelled humidity inversions were generally deeper but weaker than the observed, and often occurred independently of temperature inversions. The largest errors in temperature and humidity occurred under high pressure conditions. Multiple temperature and humidity inversions were usually not captured by WRF. Compared to the compact sea ice east of Svalbard, the modelled temperature and humidity inversions were weaker and less frequent over the fjords. The biases in modelled wind speed profiles were closely related to low-level jets (LLJs); the modelled LLJs were stronger and deeper, and typically located at higher altitudes than the observed LLJs. Errors in the near-surface variables were notably reduced by applying post-processing equations based on other modelled variables. Copyright (C) 2012 Royal Meteorological Society

Key Words: low-level jet; mesoscale modelling; topography; temperature inversion; humidity inversion; WRF

Received 15 April 2011; Revised 26 January 2012; Accepted 1 February 2012; Published online in Wiley Online Library

Citation: Kilpeläinen T, Vihma T, Manninen M, Sjöblom A, Jakobson E, Palo T, Maturilli M. 2012. Modelling the vertical structure of the atmospheric boundary layer over Arctic fjords in Svalbard. Q. J. R. Meteorol. Soc. DOI:10.1002/qj.1914

1. Introduction

In the Arctic, the atmospheric boundary layer (ABL) is usually stratified stably, and vertical profiles of air temperature, especially during the coldest months, are prominently characterized by the presence of temperature inversions (Serreze et al., 1992; Curry et al., 1996). Kahl et al. (1996) found a low-level temperature inversion in 
$91 \%$ of nearly 30000 soundings analysed from the sea-icecovered Arctic Ocean, and Serreze et al. (1992) showed that the frequency, median depth and strength of temperature inversions increased from the Norwegian Sea towards more eastern longitudes due to decreasing oceanic influences and synoptic activity. These temperature inversions are commonly formed and maintained by the negative radiation balance at the surface, but also other processes such as warmair advection (Vihma et al., 2003) and subsidence (Busch et al., 1982) can generate them. Temperature inversions in the Arctic are of great importance for climate as they represent strong vertical stability, thereby limiting the depth of vertical mixing of sensible and latent heat (Serreze and Barry, 2005).

Compared to vertical temperature profiles, much less research has been undertaken on vertical humidity profiles in the Arctic. Generally, the annual mean specific humidity decreases with height in the Arctic (Serreze et al., 1995), but in the lower troposphere inversions of specific humidity (hereafter humidity inversions) are common features (Curry et al., 1996; Sedlar and Tjernström, 2009; Devasthale et al., 2011). Humidity inversions have often been found to coincide with temperature inversions (Serreze et al., 1995), indicating that entrainment across the temperature inversion can be a source of moisture in the $\mathrm{ABL}$ and contribute to the maintenance of low-level clouds (Tjernström et al., 2004a; Sedlar and Tjernström, 2009).

Wind profiles in the stably stratified ABL are commonly characterized by a wind maximum, known as a low-level jet (LLJ). LLJs can be caused by numerous different processes such as inertial oscillations (Andreas et al., 2000), baroclinity (Vihma et al., 1998) and katabatic winds (Renfrew and Anderson, 2006). LLJs are often located near the top of the surface-based temperature inversion, near the base of an elevated inversion or within the temperature inversion layer (Andreas et al., 2000; Brümmer et al., 2005).

Only a few studies so far have addressed the vertical structure of the ABL in the Arctic in the presence of complex topography. For example, Argentini et al. (2003) made tethersonde soundings on the coast of Kongsfjorden, Svalbard, and concluded that topography and winds of local origin largely influenced the ABL over the fjord. Vihma et al. (2011) characterized temperature and humidity inversions and LLJs over Svalbard fjords and identified factors influencing them. Kilpeläinen et al. (2011) demonstrated the complex interaction between the thermodynamic and dynamic processes affecting the ABL over Arctic fjords based on mesoscale model simulations for three fjords in Svalbard. Further, simulations of Mäkiranta et al. (2011) of the flow over Wahlenbergfjorden, Svalbard, showed that katabatic flows from glaciers were lifted above the stable boundary layer over the ice-covered fjord, and the associated wind shear resulted in top-down mixing in the boundary layer. Heinemann (2003) found that synoptically forced katabatic winds resulted in the fast formation of a coastal polynya in East Greenland.

Numerical weather prediction and climate models usually have their largest errors in the stable ABL (Hunt et al., 1996; Poulos and Burns, 2003; Tjernström et al., 2004b; Atlaskin and Vihma, 2012). Progress in parametrization of the stable ABL is slow, although there have been several major experiments, e.g. the GEWEX Atmospheric BoundaryLayer Study (GABLS; e.g. Holtslag, 2006; Svensson et al., 2011). Typically, many of the operational models allow for enhanced vertical turbulent mixing in the stable $\mathrm{ABL}$ which can lead to too deep $\mathrm{ABL}$ and too high surface temperatures (Holtslag, 2006). Improvements to this issue have been demonstrated, e.g. by Brown et al. (2008), who showed that changes to the ABL scheme used in the UK Met Office operational model reduced the mixing and thereby also significantly reduced the model errors. On the other hand, modelling over sea ice is further complicated due to localized convection over leads and polynyas (Lüpkes et al., 2008) and the lack of accurate information of sea ice concentration (Valkonen et al., 2008).

Most model validations are done against near-surface measurements, where the largest model errors usually occur. Due to the lack of observations from the Arctic, evaluations of the modelled vertical structure have been comparatively scarce. However, earlier studies (e.g. Tjernström et al., 2004b; Tjernström and Graversen, 2009; Lüpkes et al., 2010; Kilpeläinen et al., 2011) have shown that there are not only notable model biases near the surface but in the whole ABL. Tjernström and Graversen (2009) found that the structure (i.e. the strength, depth and height) of the temperature inversions was fairly well captured by the European Centre for Medium-range Weather Forecasts (ECMWF) ERA-40 reanalysis on the annual scale, but case-studies have shown that models face challenges when trying to capture the detailed structure of temperature inversions (Lammert et al., 2010; Mölders and Kramm, 2010) and LLJs (Storm et al., 2008).

This study focuses on the modelling of the vertical structure of the ABL over two Arctic fjords in Svalbard in early spring. Partly ice-covered Arctic fjords, surrounded with complex topography, represent an extremely challenging modelling environment. We apply the mesoscale model Weather Research and Forecasting (WRF) and its polar optimized version, known as Polar WRF, in high-resolution simulations (section 3). The WRF is currently applied worldwide by a large user community. The WRF and Polar WRF have shown great potential in simulations of the Arctic (e.g. Bromwich et al., 2009; Mölders and Kramm, 2010), and the latter is also used for the Arctic System Reanalysis (ASR; Bromwich et al., 2010). The objectives of this study are to find out

(1) how sensitive the WRF results for the ABL are to parametrization schemes for boundary-layer turbulence and surface thermodynamics in an Arctic fjord environment;

(2) how well near-surface variables and, especially, the vertical structure of the ABL can be simulated;

(3) which are the main modelling challenges over Arctic fjords; and

(4) how inversions and LLJs over a fjord differ from those over compact sea ice.

First, twelve combinations of ABL and surface schemes are validated (section 4 ) against tethered balloon soundings and mast observations (section 2) which were also applied in Vihma et al. (2011). One of the ABL schemes used in these validations is the Quasi-Normal Scale Elimination (QNSE) scheme, evaluations of which have been scarce up to this study. Then the best combination of schemes is applied in one 16-day long simulation, results and discussion of which are presented in section 5. Finally, conclusions are drawn in section 6 . 
(a)

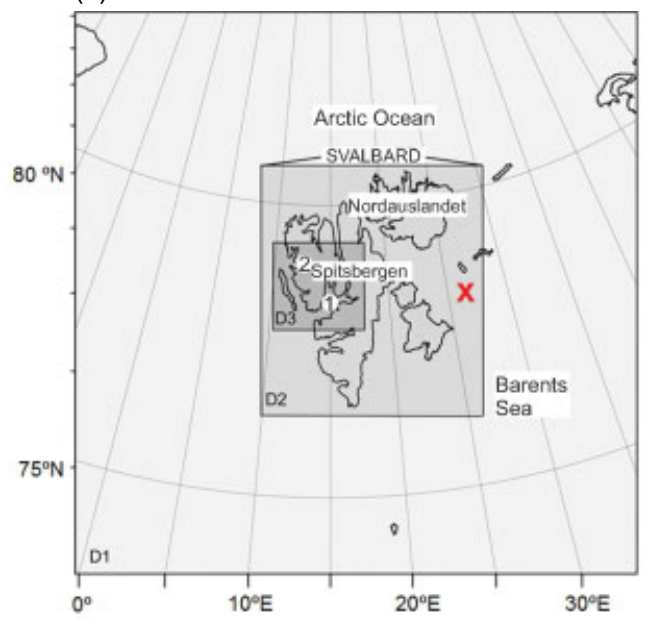

(b)

(c)
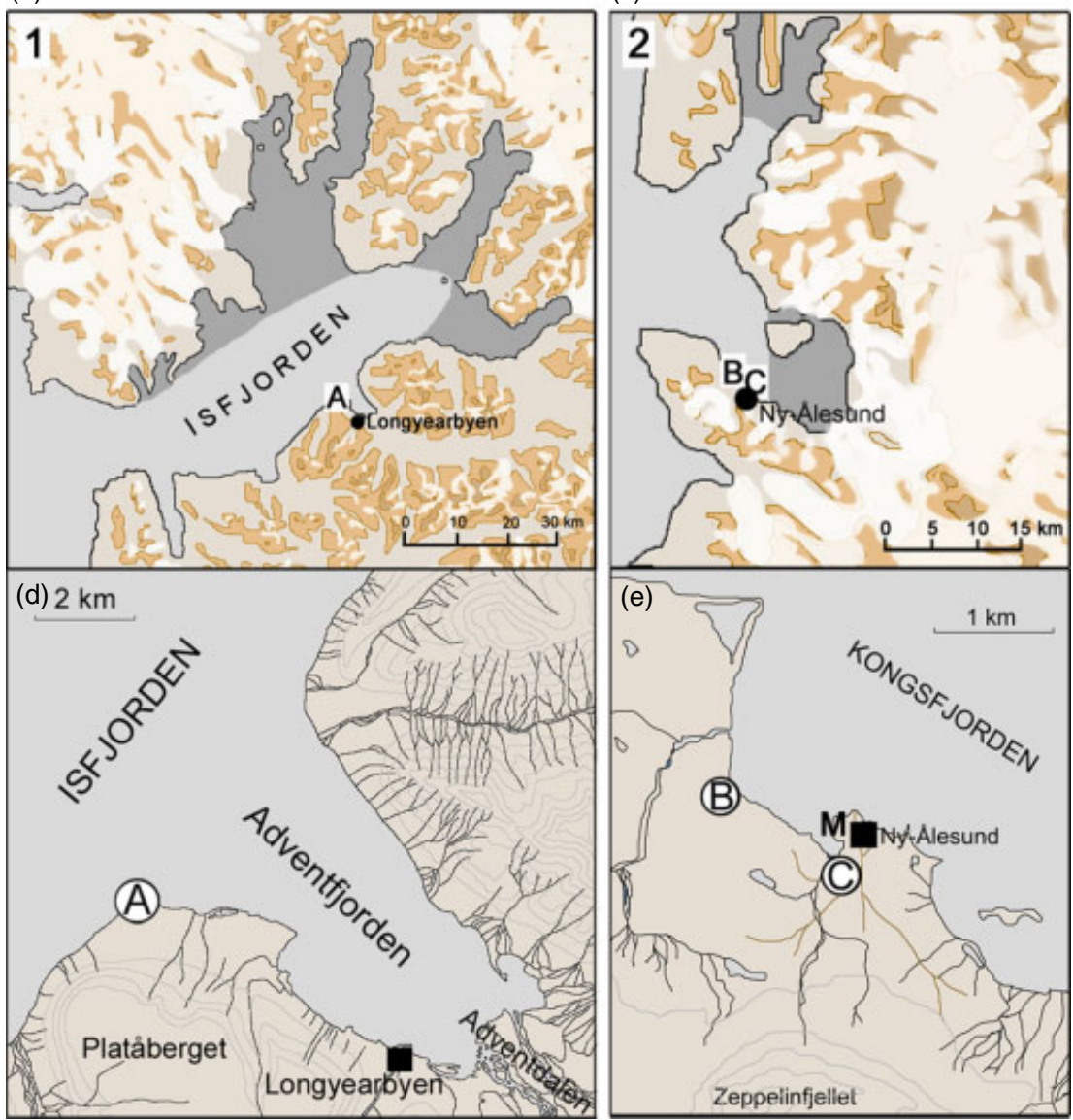

(B)

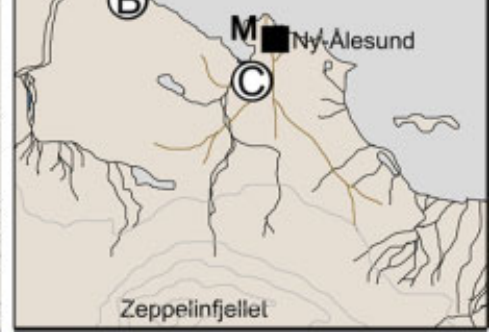

Figure 1. (a) Domains D1, D2, and D3, used in the WRF model, with 9, 3 and $1 \mathrm{~km}$ grid mesh, respectively. The locations of the observation sites in (b, d) Isfjorden and (c, e) Kongsfjorden are marked by A-C. In (a) the sea ice grid point used in comparison is marked by $x$, and in (e) the location of the University of Tartu weather mast is marked by M. In (b, c) the dark grey shading show areas with full fast ice cover and the light grey shading sea ice concentration varying between 0.2 and 0.9 . In (d, e) the terrain height is shown by $100 \mathrm{~m}$ contours. This figure is available in colour online at wileyonlinelibrary.com/journal/qj

\section{Observations}

During a measurement campaign between 21 March 2009 (day length $13 \mathrm{~h}$ ) and 5 April 2009 (day length $17 \mathrm{~h}$ ), tethered balloon soundings were made at three coastal locations in Svalbard (Figure 1) using the tethersonde system DigiCORA TT12 (Vaisala). The measurement times at these three locations were partly overlapping; 27 vertical profiles of temperature, humidity and wind were measured on the southern coast of Isfjorden (site A, $78^{\circ} 15^{\prime} \mathrm{N}, 15^{\circ} 24^{\prime} \mathrm{E}$ ) by the University Centre in Svalbard (UNIS), and 17 profiles on the southern coast of Kongsfjorden (site B, $78^{\circ} 56^{\prime} \mathrm{N}$, $11^{\circ} 51^{\prime} \mathrm{E}$ ) by the University of Tartu (UT). The top height of the soundings at sites A and B varied from $230 \mathrm{~m}$ to $1500 \mathrm{~m}$. Only the ascent data, averaged over $10 \mathrm{~m}$, were used here. At site $\mathrm{C}\left(78^{\circ} 55^{\prime} \mathrm{N}, 11^{\circ} 55^{\prime} \mathrm{E}\right)$, located on the southern coast of Kongsfjorden $1.4 \mathrm{~km}$ away from site B, the Alfred Wegener Institute (AWI) measured time series using six tethersondes kept at constant altitudes between 100 and $600 \mathrm{~m}$ above the surface at $100 \mathrm{~m}$ intervals. Vertical profiles 
for the model validation were constructed from the AWI time series by taking 10 min averages at $1 \mathrm{~h}$ intervals, which yielded 89 vertical profiles from site C. All the tethersonde measurements were done below clouds in non-precipitating conditions and wind speeds less than $10 \mathrm{~m} \mathrm{~s}^{-1}$. Due to the vicinity of the geomagnetic pole, the wind direction measurements were extremely sensitive to the tilt of the tethersonde compass. Hence, the measured wind directions were used only for identification of the origin of the air mass, not for detailed analysis. Vihma et al. (2011) provide further details of the soundings.

In addition to the tethered balloon soundings, time series of near-surface variables were collected at both fjords. In Isfjorden, measurements were taken from a $30 \mathrm{~m}$ meteorological tower equipped with sensors for wind speed and direction (A100LK and W200P, Vector Instruments), temperature and relative humidity (HMP45C, Vaisala) at several heights. However, here only the measurements at $10 \mathrm{~m}$ and surface pressure measurements (CS100, Campbell Scientific) have been used. Radiation components were measured using a net radiometer (CNR1, Kipp \& Zonen). A more detailed description of the tower measurements in Isfjorden is given in Kilpeläinen and Sjöblom (2010). In Kongsfjorden, a 10 m weather mast (Figure 1) was equipped with wind, temperature and humidity sensors (Aanderaa Data Instruments). These near-surface observations were used as the lowest level for the AWI tethersonde profiles. The radiation components were measured using pyrgeometers and pyranometers (PIR and PSP, Eppley). At both mast locations, the cloud conditions were observed visually.

At site A in Isfjorden, the fjord is $25-40 \mathrm{~km}$ wide in a $175^{\circ}$ wide marine sector, whereas at sites $\mathrm{B}$ and $\mathrm{C}$ in Kongsfjorden the width is $4-9 \mathrm{~km}$ in an approximately $150^{\circ}$ wide marine sector. The three measurement sites are surrounded by complex topography consisting of mountains, rising to the height of 400-1100 m, valleys and glaciers. Isfjorden and Kongsfjorden were partly covered with sea ice; the average sea ice concentration during the measuring period is shown in Figure 1.

\section{Model simulations}

\subsection{Models and domains}

The model simulations were made using the Advanced Research WRF (ARW) model, version 3.1.1, as well as its polar optimized version, known as Polar WRF. The ARW (hereafter called standard WRF) is developed for research and operational applications, and consists of fully compressible non-hydrostatic equations using terrainfollowing sigma coordinates (Skamarock et al., 2008). The Polar WRF is developed by the Polar Meteorology Group at the Ohio State University, optimizing the standard WRF for polar conditions with improvements, especially, to the $\mathrm{NOAH}^{*}$ land surface scheme and the snowpack treatment. The modifications in the Polar WRF are described by Hines and Bromwich (2008), Bromwich et al. (2009) and Hines et al. (2011).

\footnotetext{
*Acronym denoting collaboration between National Centers for Environmental Prediction (NCEP), Oregon State University (Dept of Atmospheric Sciences), US Air Force and the Hydrology Research Lab of the National Weather Service.
}

In all simulations, three nested polar stereographic domains with 9, 3 and $1 \mathrm{~km}$ grid mesh were used (Figure 1), following Kilpeläinen et al. (2011). These domains were one-way nested, i.e. information exchange between the parent and the nest was strictly downscale. The outermost domain D1 $(120 \times 120$ grid points $)$ covered an area from the northeast corner of Greenland in the west to Franz Josef Land in the east, whereas the middle domain D2 $(130 \times 154$ grid points) covered tightly the area of Svalbard. The innermost domain D3 $(163 \times 175$ grid points $)$ included the study areas, Isfjorden and Kongsfjorden, with a $1 \mathrm{~km}$ grid mesh. Only the results from D3 were used for the fjords, and those from D2 for the compact sea ice east of Svalbard. The land use was specified by 24-category data of the US Geological Survey. In all the domains, the model had 62 vertical levels, of which 19 were in the lowest $1000 \mathrm{~m}$ of the atmosphere; the lowest full model level was at $36 \mathrm{~m}$. In addition, a sensitivity test with 40 vertical levels, including seven levels in the lowest $1000 \mathrm{~m}$, was performed. The model top was at $50 \mathrm{hPa}$ in all simulations.

The WRF on D1 was driven by initial and lateral boundary conditions from the ECMWF Integrated Forecasting System (version 33r1; Jung et al., 2010) operational analysis with $0.5^{\circ}$ horizontal grid mesh. Perfect lateral boundaries were employed, i.e. both the initial and lateral boundary conditions were interpolated from the model analysis, at $6 \mathrm{~h}$ intervals. Data assimilation was not made in the WRF model. A fractional sea ice cover was applied in the WRF grid cells. The sea ice concentration fields were taken from the AMSR-E dataset with a resolution of $25 \mathrm{~km}$ (Cavalieri et al., 2004), and manually modified to follow the daily sea ice charts produced by the Norwegian Meteorological Institute due to errors found in the ECMWF sea ice and sea surface temperature fields in fjords and near coastlines. The sea surface temperature and sea ice fields were updated at $6 \mathrm{~h}$ intervals. In all simulations, time steps of $36 \mathrm{~s}$ (for D1), $12 \mathrm{~s}$ (for D2) and 4 s (for D3) were applied.

\subsection{Physical parametrizations}

Most of the subgrid-scale physical parametrizations, hereafter called physics options, were chosen to follow Hines and Bromwich (2008) and Kilpeläinen et al. (2011). These options included the Rapid Radiative Transfer Model (RRTM; Mlawer et al., 1997) for long-wave radiation and the Goddard scheme (Chou and Suarez, 1994) for shortwave radiation. The single-moment five-class scheme was used for cloud microphysics (Hong et al., 2004) and the Grell-Devenyi ensemble cumulus scheme (Grell and Devenyi, 2002) was applied in the outermost domain.

Several physics options for the boundary layer as well as for the land and sea ice surfaces were tested and compared. For the boundary layer, the tested options were

(1) the Mellor-Yamada-Janjic (MYJ) scheme (Janjić, 1996, 2002) run in conjunction with the Eta surfacelayer scheme;

(2) the Yonsei University (YSU) scheme (Hong et al., 2006) with a similarity theory-based surface-layer scheme; and

(3) the QNSE scheme (Sukoriansky et al., 2006).

Interesting aspects in the comparison of the performance of the schemes include: 
(a) does the MYJ scheme with a prognostic turbulent kinetic energy (TKE) outperform the other schemes in an environment with complex topography and, thus, complex processes affecting the TKE budget terms?

(b) will the explicit treatment of the entrainment layer by the YSU scheme turn out to be an essential benefit in an environment with strong inversions capping a shallow well-mixed layer? or

(c) will the focus on the stable boundary layer with turbulence-wave interactions result in a superior performance of the QNSE scheme? The QNSE scheme is a new option introduced in the WRF version 3.1.1, and little is so far known about its performance in WRF.

For the land and ice surfaces, the NOAH scheme (Chen and Dudhia, 2001) and the Rapid Update Cycle (RUC) scheme were compared. The NOAH scheme is a four-layer soil temperature and moisture model with prediction of fractional snow cover effects and frozen soil temperature, while the RUC scheme is a six-level soil temperature and moisture model with multi-layer snow and frozen soil physics. The schemes have notable differences; for example, in the NOAH scheme snow albedo is a function of solar zenith angle and snow depth while the RUC scheme has a fixed snow albedo. All these physics options were applied to both the standard and Polar WRF; an overview of the simulations and schemes used is given in Table 1. There were no significant differences in the computational cost (CPU time) of these simulations.

\subsection{Simulation strategy and synoptic conditions}

First, a $48 \mathrm{~h}$ period including $12 \mathrm{~h}$ of spin-up time, starting from 0000 UTC on 31 March 2009, was chosen for the model simulations. This $48 \mathrm{~h}$ period was simulated with both the standard and Polar WRF, using several physics options listed in Table 1; in total 12 simulations were performed. The period was characterized by observed nearsurface temperature decreasing from approximately- $15^{\circ} \mathrm{C}$ to $-25^{\circ} \mathrm{C}$, and the wind speed increasing from weak to moderate in the study areas. The geostrophic wind direction was northwesterly and the sea-level pressure was steadily increasing from approximately $1005 \mathrm{hPa}$ to $1025 \mathrm{hPa}$. The chosen period represents well the range of meteorological conditions during the measurement campaign.

Table 1. Boundary-layer and surface schemes used in the standard WRF (W) and Polar WRF (PW) simulations.

\begin{tabular}{lccc}
\hline & $\begin{array}{c}\text { Length } \\
\text { (days) }\end{array}$ & $\begin{array}{c}\text { ABL } \\
\text { scheme }\end{array}$ & $\begin{array}{c}\text { Surface } \\
\text { scheme }\end{array}$ \\
\hline W1 / PW1 & 2 & MYJ & NOAH \\
W2 / PW2 & 2 & YSU & NOAH \\
W3 / PW3 & 2 & QNSE & NOAH \\
W4 / PW4 & 2 & MYJ & RUC \\
W5 / PW5 & 2 & YSU & RUC \\
W6 / PW6 & 2 & QNSE & RUC \\
W3-40 levels & 2 & QNSE & NOAH \\
W3-long run & 16 & QNSE & NOAH \\
\hline
\end{tabular}

Abbreviations are defined in the text.
Then, a short sensitivity simulation with only 40 levels in the vertical was made using the model and physics options with the best agreement with the observations; these options are discussed in section 4

Finally, the best performing model and physics options were chosen for a 16-day model run (with 62 levels), starting from 0000 UTC on 21 March 2009 (Table 1). The 16day study period represents typical early spring weather conditions in the area. The most common geostrophic wind directions were northerly and northeasterly. During the warmest days, 28-29 March, the geostrophic wind was from the south. Figures 2 and 3 illustrate the vertical structure of modelled temperature, wind speed and specific humidity during the 16-day simulation period in Isfjorden and Kongsfjorden (site B) simulated with the long run options specified in section 4 . General features, linked to synoptic conditions, were very similar at both sites. The study period was characterized by three relatively warm and humid periods, with some cold days between (Figures 2 and 3 ). The modelled temperature, especially near the surface, was a few degrees higher and the near-surface winds were on average $2.4 \mathrm{~m} \mathrm{~s}^{-1}$ stronger in Isfjorden than at site B in Kongsfjorden. The tethered balloon soundings did not cover the whole simulation period, and their times are shown in Figures 2 and 3.

\subsection{Definitions of variables}

The cloud cover, temperature and humidity inversion, and LLJ characteristics are not standard output variables in WRF. The cloud cover was calculated using a formula given by Fogt and Bromwich (2008), with coefficients taken from the RRTM long-wave radiation scheme. Temperature inversions were defined to be layers with a temperature increase with height of at least $0.3^{\circ} \mathrm{C}$. The terminology of temperature inversions follows Andreas et al. (2000): the depth of the inversion is the difference between the altitudes where the temperature starts to increase and where the temperature starts to decrease above this layer. The temperature inversion strength is the temperature change within the inversion layer. A layer with specific humidity increase larger than $0.02 \mathrm{~g} \mathrm{~kg}^{-1}$ was here considered as a humidity inversion. The terminology is otherwise analogous to temperature inversions. A LLJ was defined as a local wind speed maximum of more than $2 \mathrm{~m} \mathrm{~s}^{-1}$ greater than wind speeds above it, following Stull (1988). A wind speed maximum at the surface was also considered as a LLJ. The altitude of maximum wind was defined as the jet core. The vertical distance between the LLJ core and the associated wind speed minimum above is defined as the LLJ depth. The wind speed difference between the core and the minimum above is the LLJ strength.

\section{Sensitivity to parametrizations}

The vertical structure, modelled with the two model versions and the selected combinations of physics options, was compared with 32 vertical profiles ( 8 at site A, 4 at site B and 20 at site C) observed during the $48 \mathrm{~h}$ simulation period. The root-mean-square error (RMSE) and bias, i.e. the observation subtracted from the modelled value, were calculated for the whole profiles and averaged over all the sites; each of the measurement sites had an equal weight in the averages. The error calculations were based on model 

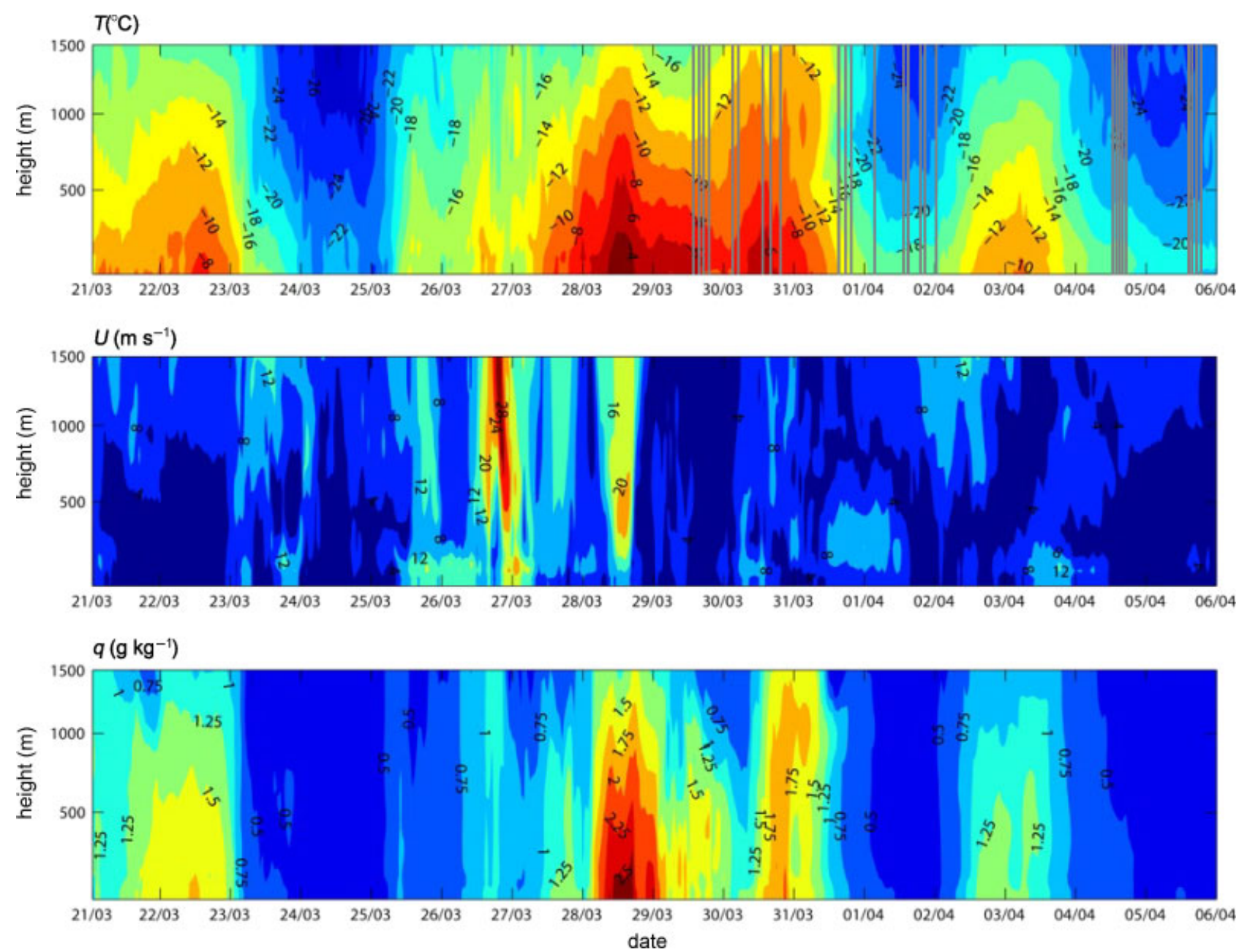

Figure 2. Temperature $T$, wind speed $U$ and specific humidity $q$ in the 16 -day simulation in Isfjorden (site A). In the top panel, the times of observations at site A are marked by vertical lines. This figure is available in colour online at wileyonlinelibrary.com/journal/qj

output from both the land and sea grid points nearest to each observation site. The results for the nearest land grid point are shown in Figure 4; the results for the sea grid point were very similar, except for slightly larger errors in wind speed. Hereafter, the results are presented only for the nearest land grid point.

Both the standard and Polar WRF yielded positive biases for temperature and specific humidity, most noticeably close to the surface (below $200 \mathrm{~m}$ ), with all the physics options tested here (Figure 4). Surprisingly, the differences between the standard WRF and Polar WRF were marginal, although the Polar WRF is optimized for Arctic conditions. The standard WRF captured most of the wind and temperature profiles slightly better than the Polar WRF, also near the surface. The specific humidity profiles were slightly better captured by the Polar WRF. However, none of these differences were statistically significant. In previous studies, the Polar WRF has outperformed the standard WRF in the Arctic (Hines and Bromwich, 2008; Bromwich et al., 2009; Hines et al., 2011). However, Tastula and Vihma (2011) concluded that the standard WRF gave results almost as good as the Polar WRF in very stably stratified winter conditions in Antarctica. Compared to earlier studies with the Polar WRF, our simulations had a notably higher horizontal resolution. As the Polar WRF is optimized and tested for a $25 \mathrm{~km}$ grid mesh, the high resolution of our simulations might at least partly explain why the Polar WRF did not yield better results. Further, as the treatment of fractional sea ice (Bromwich et al., 2009)-one of the major advantages in the Polar WRF-is now also included in the standard WRF version 3.1.1, differences between the standard and Polar WRF were smaller than in earlier comparisons.

The physics options had a notable impact, especially on the temperature and specific humidity profiles. The average differences between the model runs reached almost $2{ }^{\circ} \mathrm{C}$ for temperature and up to $0.1 \mathrm{~g} \mathrm{~kg}^{-1}$ for the specific humidity profiles (Figure 4); the combination of YSU and RUC yielded RMSE and bias of more than twice those from the combination of MYJ/QNSE and NOAH. Interestingly, the RMSE and bias of temperature and specific humidity were close to equal below $200 \mathrm{~m}$, which suggests that the variability of the model error was small. The NOAH land surface scheme systematically resulted in smaller errors for the temperature and humidity than the RUC scheme. The differences were caused by different snow thermodynamics, including differences in the snow depth and albedo, the latter often having a dominating role in the schemes (Slater et al., 2001). The wind speed bias was very small with all the physics options, while the RMSE of wind speed was large. Of the three boundary-layer schemes tested here, the YSU scheme yielded the largest errors in the vertical profiles. Hines and Bromwich (2008) came to a similar conclusion when they compared the MYJ and YSU schemes for Greenland. Indeed, in the development of the YSU scheme the focus was on 

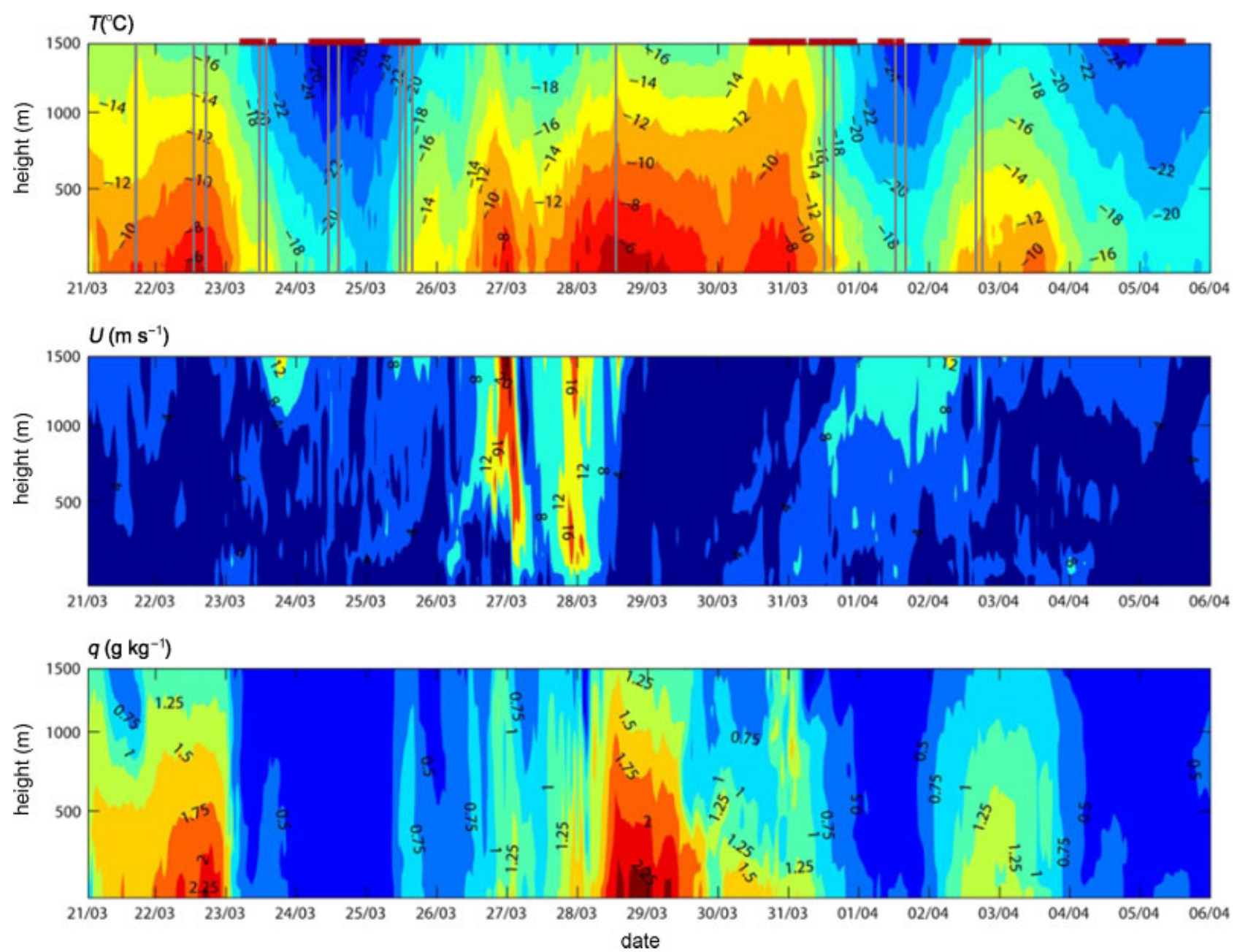

Figure 3. Temperature $T$, wind speed $U$ and specific humidity $q$ in the 16-day simulation in Kongsfjorden (site B). In the top panel, the times of observations at site $\mathrm{B}$ are marked by vertical lines, and those at site $\mathrm{C}$ by horizontal bars. This figure is available in colour online at wileyonlinelibrary.com/journal/qj

the convective boundary layer (Hong et al., 2006) instead of Arctic conditions. The MYJ scheme worked best for some of the coldest profiles, suggesting that the prognostic TKE was beneficial in very stable conditions over complex topography. However, on average, the new QNSE scheme, where the scale-dependent description of the turbulent flow particularly affects the stable ABL parametrization, was slightly better than the MYJ scheme. Evaluations of the QNSE scheme have so far been very scarce. However, simulations of Sukoriansky and Galperin (2008) with the High-Resolution Limited-Area Model (HIRLAM) showed that the QNSE scheme notably reduced the warm bias in stable winter conditions over Scandinavia. Thus, the best overall agreement with the observations was achieved by using the standard WRF together with the QNSE scheme for the boundary layer and the NOAH scheme for the land and sea ice surfaces. These physics options were selected for the 16-day simulation (section 5) and are hereafter called long run options.

The sensitivity of the long run options to the vertical resolution was tested by decreasing the number of vertical levels from 62 to 40 . The bias of wind speed increased by $0.3 \mathrm{~m} \mathrm{~s}^{-1}$ and the RMSE of wind speed by $0.1 \mathrm{~m} \mathrm{~s}^{-1}$ when the coarser vertical resolution was used. The coarser resolution also increased the RMSE of profiles of temperature and specific humidity by $0.03{ }^{\circ} \mathrm{C}$ and $0.02 \mathrm{~g} \mathrm{~kg}^{-1}$, respectively.
In summary, the results were much more sensitive to the choice of physics options than to the vertical resolution. Furthermore, WRF's notable sensitivity to horizontal resolution over Svalbard fjords has earlier been pointed out by Kilpeläinen et al. (2011).

\section{16-day experiment}

\subsection{Near-surface variables}

The average errors and correlation coefficients between the observed and modelled near-surface variables and the cloud fraction for the 16-day run are shown in Table 2. The model showed a very good skill in simulating surface pressure. Further, both the temperature and humidity correlations were strong at both sites, although there was a large warm bias in Kongsfjorden. The modelled wind speed and cloud fraction had notably weaker correlations with the observations (correlation coefficient $r=0.4$ to 0.6 , $p<0.01$ ). Realistic simulation of cloud fraction has also been a problem for several regional climate models in the Arctic (Rinke et al., 2006) and for WRF in the Antarctic (Fogt and Bromwich, 2008).

To identify factors controlling the model error of wind speed, temperature and specific humidity near the surface, correlation analyses were made, first by applying the 


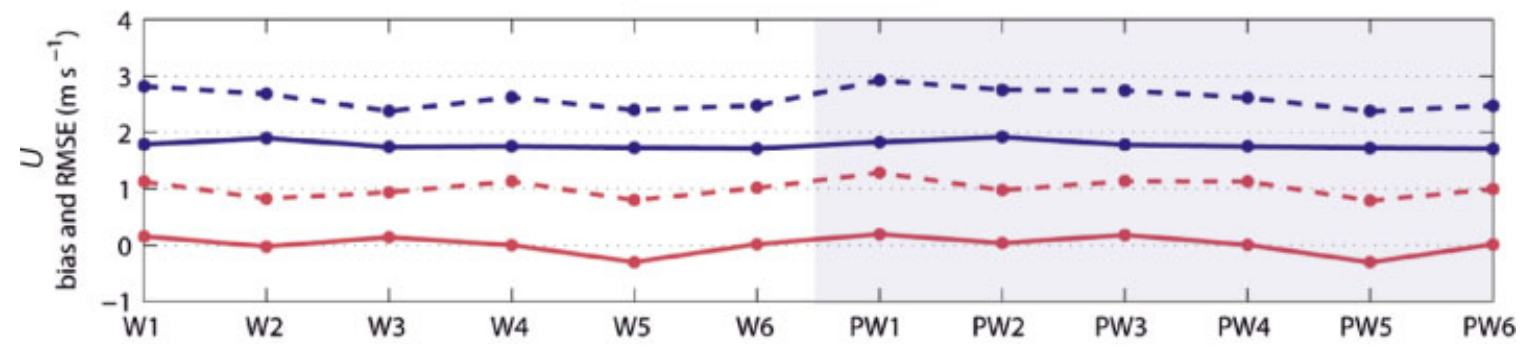

(b)
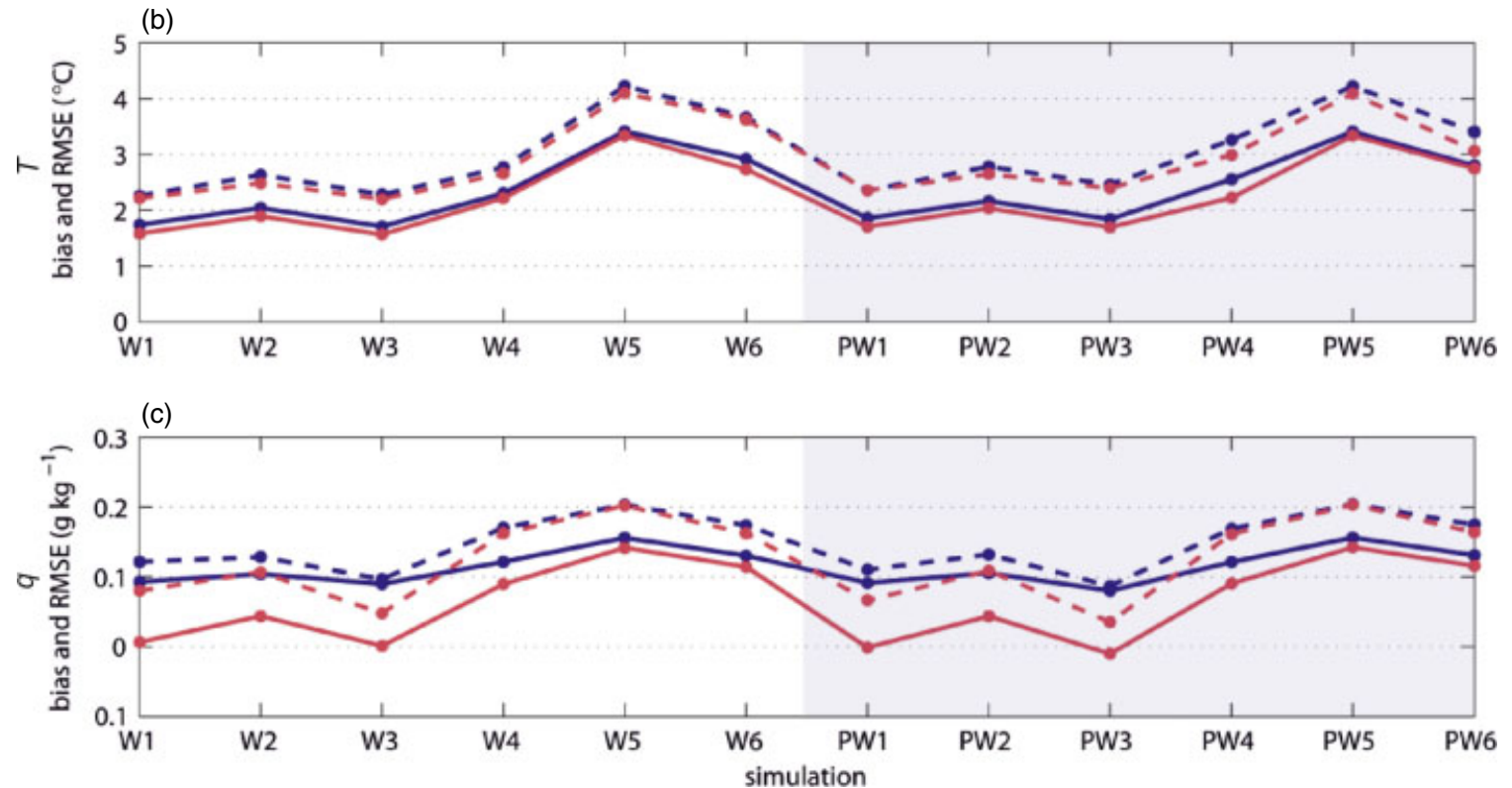

Figure 4. Bias and RMSE of (a) wind speed $U$, (b) temperature $T$, and (c) specific humidity $q$. The solid lines indicate the values averaged over all measurement heights and sites, and the dashed lines the average values for the lowest $200 \mathrm{~m}$. Simulations with the standard WRF and the Polar WRF are marked by W and PW, respectively. The physics options used in the simulations are indicated with numbers: $1=\mathrm{MYJ}-\mathrm{NOAH}, 2=\mathrm{YSU}-\mathrm{NOAH}$, 3=QNSE-NOAH, 4=MYJ-RUC, $5=$ YSU-RUC, and 6=QNSE-RUC. This figure is available in colour online at wileyonlinelibrary.com/journal/qj

Table 2. The bias and RMSE of simulated near-surface wind speed $U$, air temperature $T$, specific humidity $q$, surface pressure $p$ and cloud cover fraction $N$ during the 16-day simulation period.

\begin{tabular}{|c|c|c|c|c|c|c|c|c|c|}
\hline & \multirow[b]{2}{*}{ Height (m) } & \multicolumn{4}{|c|}{ Isfjorden } & \multicolumn{4}{|c|}{ Kongsfjorden } \\
\hline & & Bias & RMSE & $r$ & $n$ & Bias & RMSE & $r$ & $n$ \\
\hline$U\left(\mathrm{~m} \mathrm{~s}^{-1}\right)$ & $10 / 5$ & 0.6 & 2.7 & 0.6 & 369 & 1.3 & 2.4 & 0.4 & 369 \\
\hline$T\left({ }^{\circ} \mathrm{C}\right)$ & $10 / 2$ & 0.7 & 2.4 & 0.8 & 369 & 2.5 & 3.4 & 0.8 & 369 \\
\hline$q\left(\mathrm{~g} \mathrm{~kg}^{-1}\right)$ & $10 / 2$ & -0.02 & 0.3 & 0.8 & 369 & 0.2 & 0.3 & 0.8 & 369 \\
\hline$p(\mathrm{hPa})$ & surface & 0.06 & 1.2 & 1.0 & 369 & 0.6 & 1.6 & 0.9 & 369 \\
\hline$N$ (fraction) & all & 0.04 & 0.3 & 0.5 & 107 & -0.01 & 0.3 & 0.4 & 38 \\
\hline
\end{tabular}

$r$ is the correlation coefficient between the measured and simulated variables (all are are significant, $p<0.01$ ).

$n$ is the number of observations. The measuring heights are given for Isfjorden/Kongsfjorden.

observed near-surface variables, cloud cover, inversion and LLJ properties as well as variables at the $850 \mathrm{hPa}$ level taken from the ECMWF operational analyses, and then by applying the above-mentioned variables taken from the WRF simulations.

The correlation analysis with observed variables indicated that conditions both in the ABL and above it (at the $850 \mathrm{hPa}$ level) were connected to the magnitude and sign of the model error (Table 3). Although many of these correlations were notably different for Isfjorden and Kongsfjorden, several common relationships were found. For example, both observed surface pressure and $850 \mathrm{hPa}$ geopotential height had a positive correlation with the error in nearsurface temperature and specific humidity $(r=0.2$ to 0.6$)$, and a negative correlation with the error in wind speed $(r=$ -0.3 to -0.2$)$. Generally, the largest magnitudes of errors in temperature and humidity occurred under high pressure conditions. As the high pressure conditions typically are characterized by a weak wind, the error in temperature and humidity also had a negative correlation coefficient with the near-surface wind speed ( $r=-0.6$ to -0.4$)$. The temperature error also correlated positively with the 
observed temperature inversion depth, and the magnitude of the error was largest when a strong temperature inversion was observed. The latter is in accordance with Atlaskin and Vihma (2012) who validated four numerical weather prediction models in a boreal forest.

The correlation analysis showed that the model error was often also connected to modelled variables. For temperature and humidity error, correlations with the modelled surface pressure and $850 \mathrm{hPa}$ geopotential height were very similar to the correlations with the observed pressure variables due to the model's high skill in simulating pressure (Table 3). Hence, synoptic situations notably affected the model performance over the fjords, as the error was clearly dependent on atmospheric pressure. High pressure conditions, which often lead to very stable ABLs, are a real challenge for WRF. The geopotential height and pressure were the main predictors, whereas the other, more local, model variables tested as predictors were not able to significantly improve the forecasts locally. Further, on the basis of an analysis of humidity and related variables (e.g. cloud fraction and incoming long-wave radiation), we found that the model error of near-surface specific humidity was largest in moist conditions. Moreover, the modelled near-surface wind speed correlated positively with the wind speed error ( $r=0.6$ to 0.7 ).

Significant correlations of model error with modelled variables indicate potential for post-processing of the model results using modelled variables. Based on simple (bilateral) and multiple linear regression analyses, best fit adjustment equations for the modelled $2 \mathrm{~m}$ temperature and $2 \mathrm{~m}$ specific humidity were built up. As the same data were used both in construction and validation of the adjustments, the reductions of model errors should be considered as upper bounds. Figure 5 shows a comparison of the error with and without these adjustments. The adjustment for temperature based on the geopotential height at $850 \mathrm{hPa}$ reduced the RMSE notably especially in Kongsfjorden, where the reduction was from $3.4{ }^{\circ} \mathrm{C}$ (Table 2) to $2.5^{\circ} \mathrm{C}$. For the specific humidity, the adjustment based on the geopotential height at $850 \mathrm{hPa}$ and $2 \mathrm{~m}$ relative humidity worked best in Kongsfjorden; it reduced the RMSE from $0.30 \mathrm{~g} \mathrm{~kg}^{-1}$ (Table 2) to $0.21 \mathrm{~g} \mathrm{~kg}^{-1}$.

\subsection{Vertical profiles}

Figure 6 shows the biases and RMSEs of the modelled profiles for the 16-day simulation. The observed values were interpolated to the model levels, except for the data from Kongsfjorden site C, where the interpolation was made to the measurement levels due to the coarse vertical resolution of the observed profiles. Note that the number of observations included in the mean values decreases with height (section 2). Error values for the long simulation resembled those for the short simulation with the same physics options (Figure 4). The main differences were that the temperature bias was approximately $1{ }^{\circ} \mathrm{C}$ smaller and the RMSE of specific humidity almost $0.1 \mathrm{~g} \mathrm{~kg}^{-1}$ higher in the long simulation.

The wind speed profile bias had more spatial variation than the temperature and humidity biases since the study areas are characterized by complex topography and thereby influenced by local wind patterns. The wind speed had relatively large errors near the surface, where the model overestimated the mean wind speed in Kongsfjorden, and underestimated it in Isfjorden (Figure 6). Related to the LLJ height, the sign of the wind speed bias varied notably with height. In Isfjorden, the observed and modelled mean heights of LLJs were $110 \mathrm{~m}$ and $180 \mathrm{~m}$, respectively. This led to a negative bias around $100 \mathrm{~m}$, which turned into a positive bias higher in the ABL where the modelled LLJs occurred. In Kongsfjorden, the LLJs were commonly observed at 200-300 m, but the modelled LLJs were typically found at $400 \mathrm{~m}$ at site B and at 20-50 $\mathrm{m}$ at site C. This incompatibility explains that the largest negative bias was located at $300 \mathrm{~m}$ and the most positive bias near the surface and at 400-500 m at site B (Figure 6).

The simulations also had a clear warm bias near the surface (Figure 6) related to temperature inversions. The errors in temperature generally decreased with altitude, which is in agreement with e.g. the WRF results of Hines et al. (2011) for the Arctic. The vertical profiles of specific humidity bias and RMSE closely resembled the WRF results of Kilpeläinen et al. (2011) for Kongsfjorden, indicating that the largest errors occurred near the surface and above $500 \mathrm{~m}$ altitude. Humidity inversions were common near the surface, and the model's weakness to capture these inversions contributed

Table 3. Correlation of observed and modelled variables with the model error of wind speed $U$, temperature $T$ and specific humidity $q$ near the surface. A range is given when results were different for Isfjorden and Kongsfjorden.

\begin{tabular}{|c|c|c|c|c|}
\hline & Observed variables & $r$ & Model variables & $r$ \\
\hline \multirow[t]{3}{*}{$U$ error } & $850 \mathrm{hPa}$ geopotential & -0.3 to $[-0.2]$ & $850 \mathrm{hPa}$ geopotential & -0.3 to -0.2 \\
\hline & Surface $p$ & -0.2 & Surface $p$ & -0.2 \\
\hline & Near-surface $U$ & -0.2 & Near-surface $U$ & 0.6 to 0.7 \\
\hline \multirow[t]{5}{*}{$T$ error } & $850 \mathrm{hPa}$ geopotential & 0.3 to 0.6 & $850 \mathrm{hPa}$ geopotential & 0.4 to 0.6 \\
\hline & Surface $p$ & 0.3 to 0.5 & Surface $p$ & 0.3 to 0.4 \\
\hline & Near-surface $U$ & -0.6 & Near-surface $U$ & -0.4 to -0.3 \\
\hline & $T$ inversion strength and depth & {$[0.4]$ to 0.6} & & \\
\hline & Near-surface $T$ & -0.5 to -0.3 & & \\
\hline \multirow[t]{6}{*}{$q$ error } & $850 \mathrm{hPa}$ geopotential & 0.2 to 0.6 & $850 \mathrm{hPa}$ geopotential & 0.3 to 0.5 \\
\hline & Surface $p$ & 0.2 to 0.5 & & \\
\hline & Near-surface $U$ & -0.4 & Near-surface $U$ & -0.4 \\
\hline & & & Near-surface $R H$ & 0.5 to 0.7 \\
\hline & & & $850 \mathrm{hPa} R H$ & 0.3 \\
\hline & & & Near-surface $q$ & 0.2 to 0.6 \\
\hline
\end{tabular}

All correlations are significant $(p<0.01)$ except those marked [..]. 


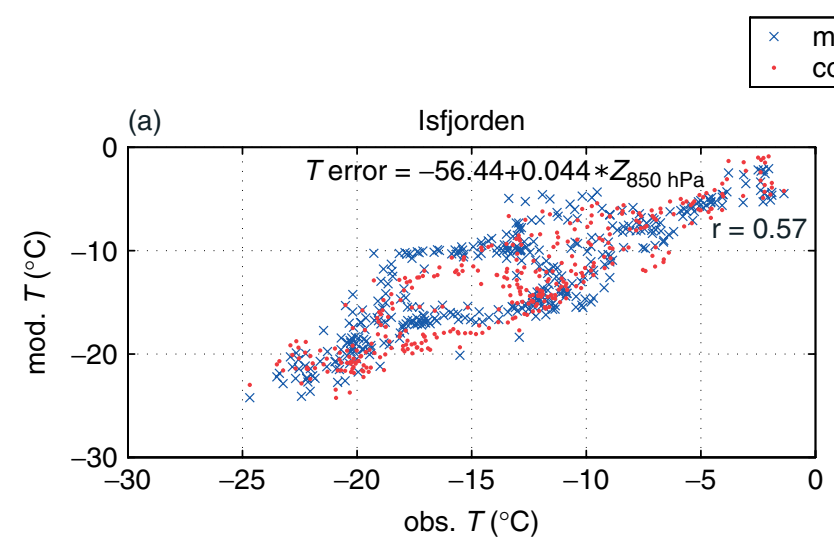

corrected model
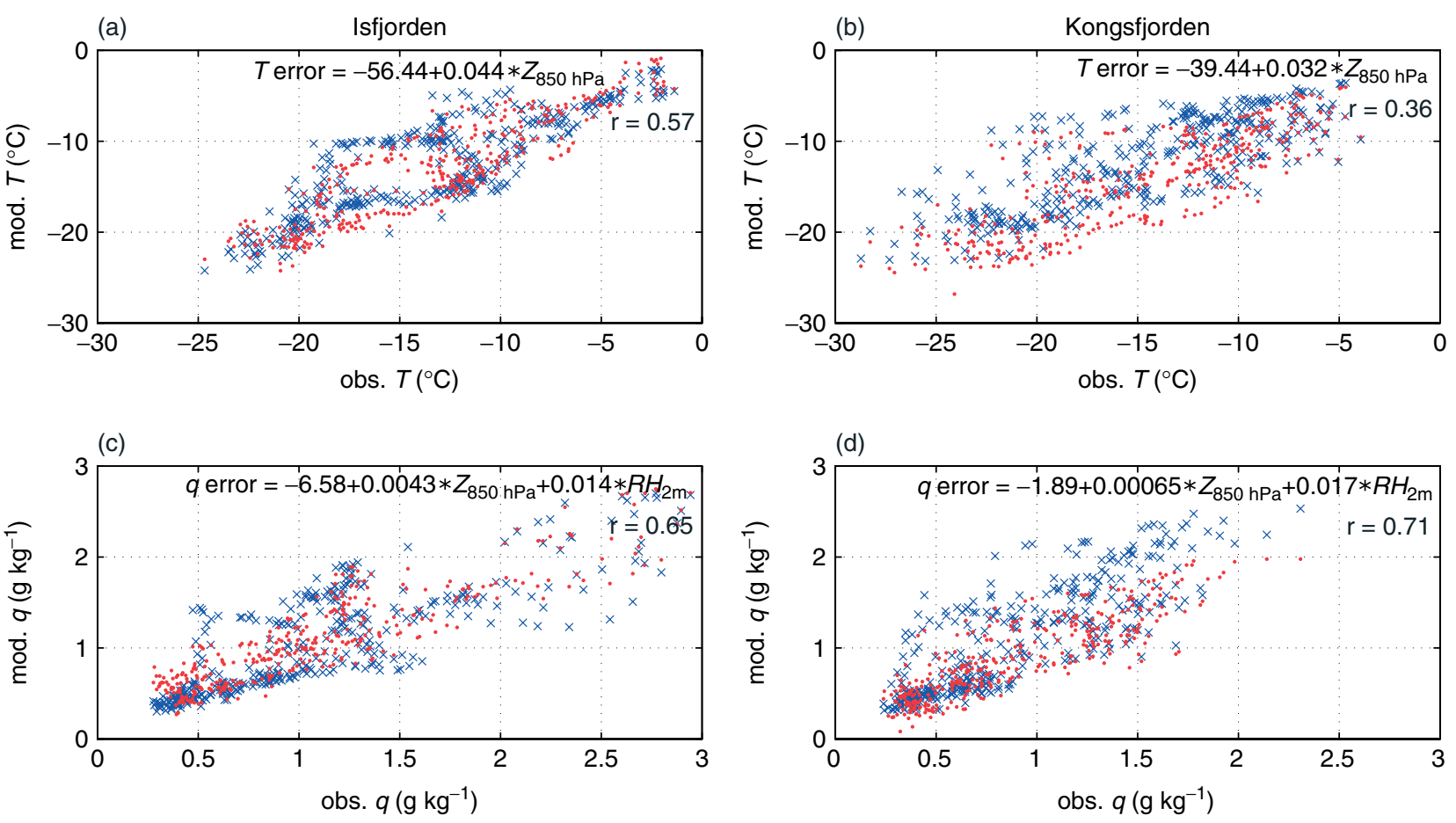

Figure 5. Comparisons of modelled near-surface $(\mathrm{a}, \mathrm{b})$ temperature $T$, and $(\mathrm{c}, \mathrm{d})$ specific humidity $q$ with observations at Isfjorden and Kongsfjorden. Dots denote adjusted model results applying the post-processing equations shown. The correlation coefficient, $r$, indicates the dependency between the model error and its adjustment equation; all the correlation coefficients are significant $(p<0.01)$. Variables in the equations are the geopotential height at $850 \mathrm{hPa}\left(Z_{850 \mathrm{hPa}}\right)$ and the relative humidity at $2 \mathrm{~m}\left(R H_{2 \mathrm{~m}}\right)$. This figure is available in colour online at wileyonlinelibrary.com/journal/qj

to the large bias. The absolute errors in the modelled specific humidity were largest under warm and moist conditions.

Comparing the fjords, the model results, especially near the surface, were better over Isfjorden than Kongsfjorden. In addition to topography, the sea ice cover could explain some of these differences between the fjords; Kongsfjorden was partly frozen while Isfjorden was mostly open. Isfjorden is also larger, which leads to a better model performance.

The relationships between the profile errors and the observed variables were generally less consistent than they were for the near-surface variables (section 5.1). The error of the wind speed profile had a negative correlation with wind speed at $850 \mathrm{hPa}(r=-0.5$ to -0.3$)$, and the error turned negative with high wind speeds at $850 \mathrm{hPa}$ (Table 4). In Isfjorden, the error of the modelled temperature profiles correlated positively with the temperature inversion strength and depth ( $r=0.6$ to 0.7 ), but in Kongsfjorden (site B) the correlation had an opposite sign $(r=-0.8$ to -0.6$)$. This unexpected relationship between the negative error of the temperature profiles and deep inversions at site B was caused by an underestimation of the temperatures in the whole profile in addition to the model's failure to capture a strong temperature inversion. The error of the specific humidity profiles was strongly associated with cloud cover, incoming long-wave radiation and specific and relative humidity at $850 \mathrm{hPa}$, which are closely related variables (Table 4). Increasing cloud cover, leading to increased incoming longwave radiation, increased the positive error of the modelled humidity profiles.
Table 4. Correlation of observed variables with the model errors, as in Table 3 but over the whole profiles.

\begin{tabular}{llc}
\hline & Observed variables & $r$ \\
\hline$U$ error & 850 hPa geopotential & -0.3 to -0.2 \\
& Surface $p$ & -0.2 \\
& Near-surface $U$ & -0.5 to $[-0.3]$ \\
$T$ error & $T$ inversion & -0.8 to 0.6 \\
& strength and depth & \\
& Surface $p$ & 0.3 to 0.5 \\
& Near-surface $U$ & -0.4 to -0.3 \\
& Near-surface $T$ & -0.5 to -0.3 \\
& Cloud fraction & {$[0.2]$ to 0.9} \\
& Near-surface $T$ & {$[0.3]$ to 0.8} \\
& 850 hPa $T$ & {$[0.3]$ to 0.7} \\
& Incoming LW & {$[0.2]$ to 0.7} \\
& 850 hPa $R H$ & -0.4 to $[-0.1]$ \\
\hline
\end{tabular}

\subsubsection{Temperature inversions}

Temperature inversions were found in $82 \%$ of the observed profiles and $53 \%$ of the modelled profiles. All together 163 temperature inversions were observed during the campaign, and 80 were found in the modelled profiles (Table 5). Surface-based inversions were clearly the most common inversion type both in the observations and model results. In addition, multiple inversions were commonly found in the observations, but rarely in the modelled profiles. Figure $7(\mathrm{a}, \mathrm{b})$ show the comparison between the observed and modelled temperature inversion statistics. The modelled inversions 

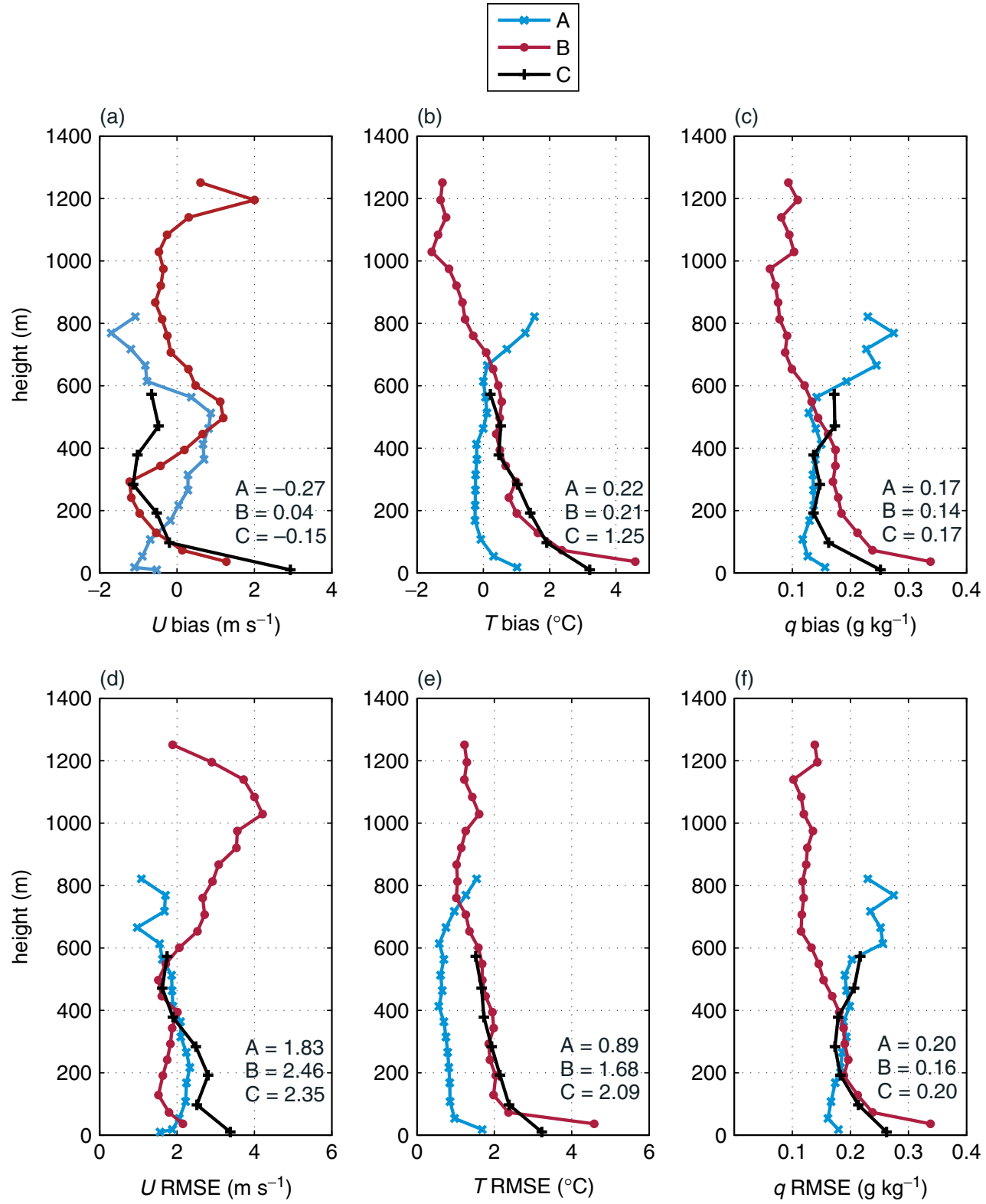

Figure 6. Vertical profiles of the (a, b, c) bias and (d, e, f) RMSE of ( $\mathrm{a}, \mathrm{d}$ ) wind speed $U$, (b, e) temperature $T$, and (c, f) specific humidity $q$ profiles at Isfjorden site A, Kongsfjorden site B, and Kongsfjorden site C. The numbers show the bias and RMSE averaged over the whole profile at each site. This figure is available in colour online at wileyonlinelibrary.com/journal/qj

Table 5. Number of temperature $T$ and humidity $q$ inversions and low-level jets in the observed and modelled profiles. The number of profiles which have one or more inversions/jets is given in brackets.

\begin{tabular}{|c|c|c|c|c|c|}
\hline & & All & $\begin{array}{c}\text { Isfjorden } \\
\text { (site A) }\end{array}$ & $\begin{array}{c}\text { Kongsfjorden } \\
\quad(\text { site B) }\end{array}$ & $\begin{array}{c}\text { Kongsfjorden } \\
\text { (site C) }\end{array}$ \\
\hline \multirow[t]{2}{*}{$T$ inversions } & Observations & 163 (109) & $41(25)$ & $45(17)$ & 77 (67) \\
\hline & Model & $80(70)$ & $14(13)$ & $6(4)$ & $60(53)$ \\
\hline \multirow{2}{*}{$q$ inversions } & Observations & $208(104)$ & $76(27)$ & $50(17)$ & $82(60)$ \\
\hline & Model & $67(63)$ & $14(14)$ & $6(6)$ & $47(43)$ \\
\hline \multirow[t]{2}{*}{ Low-level jets } & Observations & $77(71)$ & $23(20)$ & $13(10)$ & $41(41)$ \\
\hline & Model & $95(88)$ & $18(15)$ & $13(11)$ & $64(62)$ \\
\hline
\end{tabular}

were markedly thinner than the observed inversions, and the modelled depth often remained below $50 \mathrm{~m}$ (Figure 7(a)). Furthermore, the strength of the inversion (Figure 7(b)) was typically underestimated by the model. WRF's tendency to underestimate the temperature inversion strength was also reported by Mölders and Kramm (2010). Moreover, several other numerical weather prediction models as well as reanalyses (Tjernström and Graversen, 2009) suffer from underestimation of temperature inversion strength. Too weak and thin temperature inversions and warm bias in the near-surface temperature in the model suggest deficits in the representation of the surface energy balance and excessive 

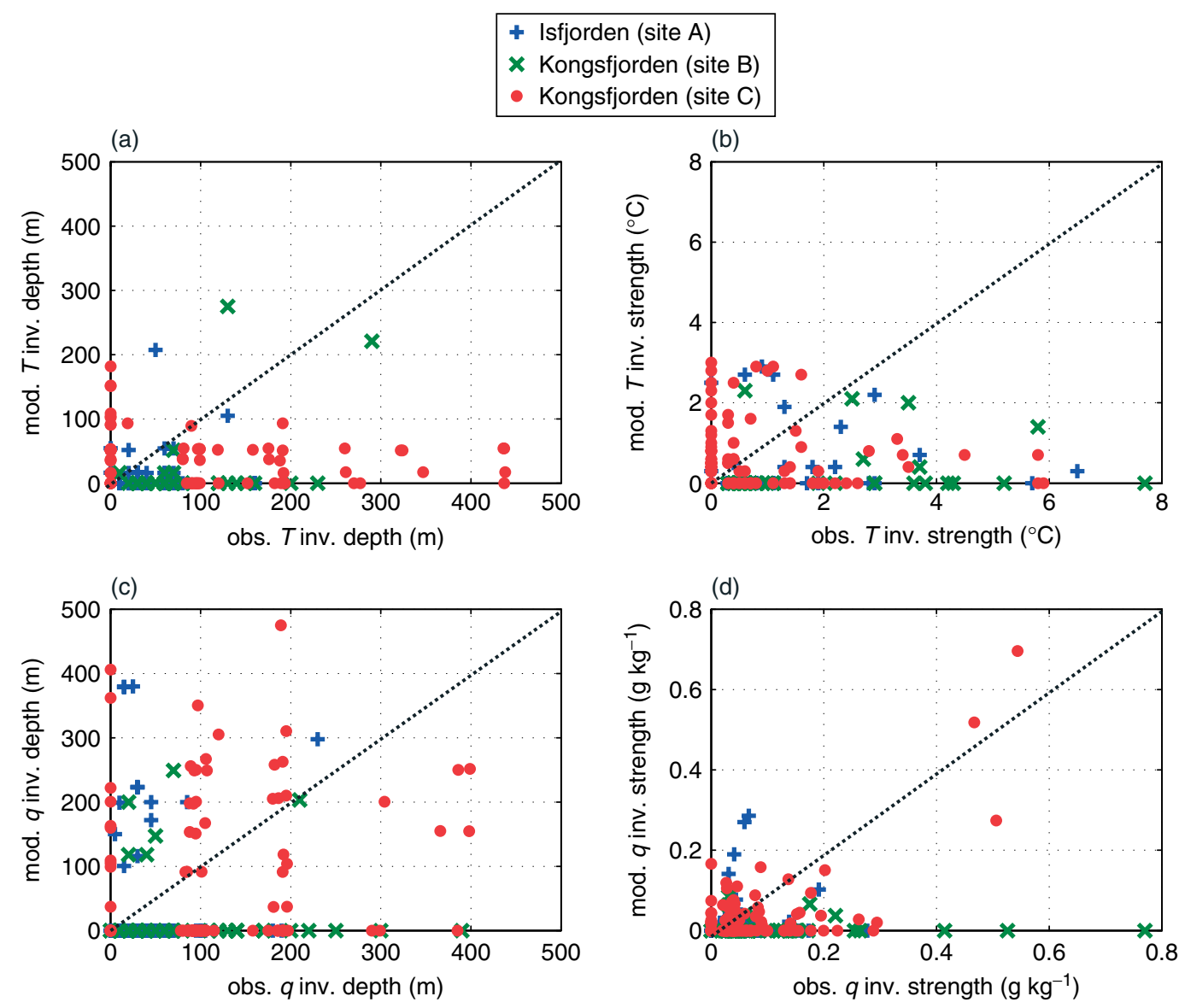

(e)
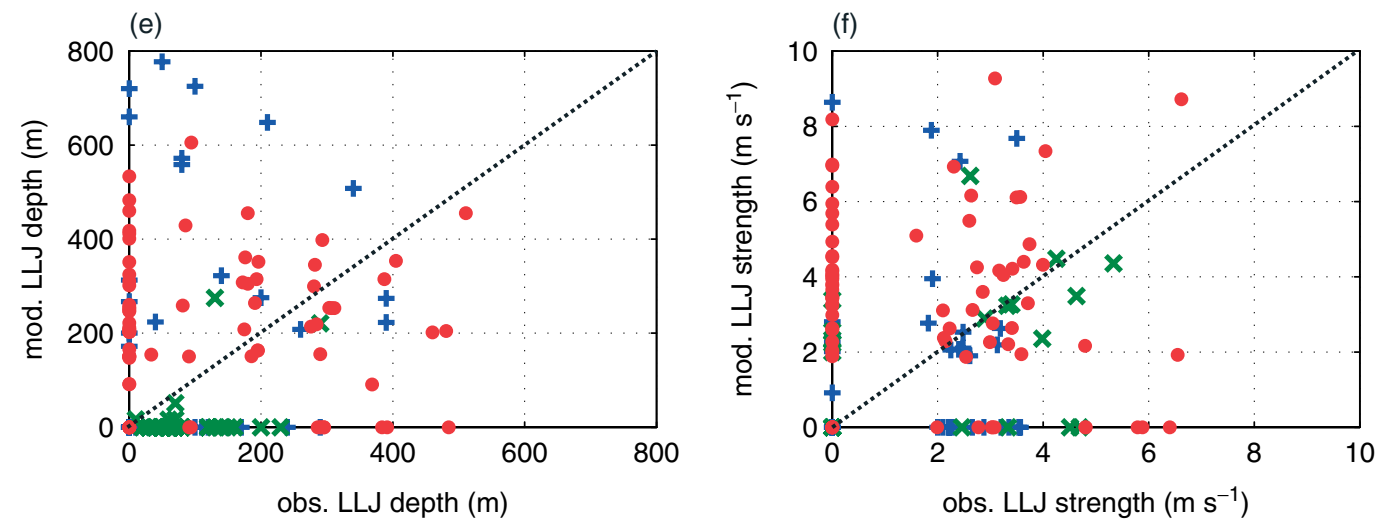

Figure 7. Comparisons of observed and modelled (a) temperature inversion depth, (b) temperature inversion strength, (c) humidity inversion depth, (d) humidity inversion strength, (e) low-level jet depth, and (f) low-level jet strength. This figure is available in colour online at wileyonlinelibrary.com/journal/qj

vertical mixing in the ABL, which are typical problems in the stable ABL in models (Holtslag, 2006; Atlaskin and Vihma, 2012). For example, Hines et al. (2011) found that reduced soil heat conductivity in the Polar WRF resulted in improved results with a reduced warm bias near the surface. On the other hand, Mölders and Kramm (2010) suggested that WRF's tendency to overestimate the wind speed could partly explain the difficulties in capturing the strength of the temperature inversions because low wind speeds are favourable for temperature inversion formation. Our results indicated that strong temperature inversions were favoured by low humidity and cloud-free conditions both in the model and observations, but a significant correlation with the modelled wind speed was not found. Nevertheless, the near-surface temperature error was negatively correlated with the near-surface wind speed (section 5.1).
Neither the observed and modelled inversion strength nor the observed and modelled inversion depth correlated well. The modelled base temperature and especially the inversion-top temperature were fairly close to the observed ones, when an inversion was present both in the model and observations. However, only $37 \%$ of the observed inversions were captured by the model. The strength of the temperature inversions not captured by the model varied from 0.3 to $8.0{ }^{\circ} \mathrm{C}$. The strongest inversion not captured by the model was observed in Kongsfjorden on 25 March during a case of warm-air advection, when a strong inversion was observed in the lowermost $150 \mathrm{~m}$, i.e. below the advection layer. Meanwhile, the modelled temperature profile had its maximum at the surface. Hence, WRF in our simulations was not able to reproduce the stable internal boundary layer under warm air advection. The model, in 
turn, produced 18 inversions that were not seen in the observations. Most of these cases occurred at site $\mathrm{C}$ in Kongsfjorden and can partly be explained by the coarse vertical resolution $(100 \mathrm{~m})$ of the AWI observations which did not resolve thin inversion layers. In general, the model captured an observed inversion layer more often under very cold conditions, although inversions were observed over a wide range of temperatures.

Correlations of the observed and modelled temperature inversion properties with other variables were compared. Temperature inversion depth and strength were highly correlated in the observations (Vihma et al., 2011), but, surprisingly, no such correlation was found in the model results. The observed temperature inversion depth had a significant correlation with the $850 \mathrm{hPa}$ temperature and low cloud cover (Vihma et al., 2011). The modelled temperature inversion depth, in turn, had a significant correlation only with the modelled near-surface wind direction; the modelled temperature inversion depth was largest when the modelled wind was from north, i.e. from the fjords. The observed temperature inversion strength correlated negatively with the $850 \mathrm{hPa}$ relative humidity (Vihma et al., 2011). In the model results, no significant correlation was found with $850 \mathrm{hPa}$ humidity, but a negative correlation with modelled cloud fraction was seen instead.

\subsubsection{Humidity inversions}

All the observed profiles from Isfjorden and Kongsfjorden site B had one or several specific humidity inversions, but at site $\mathrm{C}$ in Kongsfjorden, partly due to coarse vertical resolution, a humidity inversion was identified only in $67 \%$ of the profiles (Table 5 ). In comparison, only $47 \%$ of the modelled profiles had a humidity inversion. In total, 208 humidity inversions were identified in the observed profiles and 67 in the modelled profiles. $28 \%$ of the observed profiles and $11 \%$ of the modelled profiles had a surface-based humidity inversion. Nearly all the observed profiles from Isfjorden and Kongsfjorden site B had multiple humidity inversion layers, which is in accordance with Devasthale et al. (2011) who observed that, in the Arctic, multiple humidity inversions are much more common than single-inversion layers. However, the model always failed to capture these multiple inversions. Figure $7(\mathrm{c}, \mathrm{d})$ show the observed and modelled humidity inversion statistics. The observed humidity inversions were typically thinner than $100 \mathrm{~m}$, while the inversions identified in the modelled profiles were often several hundreds of metres deep. Nevertheless, the observed humidity inversions were often stronger than the modelled inversion, although the actual specific humidities at the inversion bottom and top were higher in the modelled profiles. Neither the observed and modelled inversion strength nor the observed and modelled inversion depth correlated well. The poor reproducibility of humidity inversions indicates problems in the column thermodynamics, as pointed out by Devasthale et al. (2011). In our modelled profiles, the humidity inversion base was often within the temperature inversion layer and the humidity inversion top above the temperature inversion top, but our observations showed humidity inversions both within and above the temperature inversions. The humidity inversions were thus not directly associated with the temperature inversions, and could occur independently. These results are not fully in accordance with Tjernström et al. (2004a), who found that in contrast to the ABL in midlatitudes, the specific humidity often increases across the temperature inversions. However it is noteworthy that their results were for the summertime Arctic ABL.

The modelled humidity inversion depth and strength, as well as observed depth and strength at site C, were positively correlated. The observed humidity inversion depth had little statistical relationship with other variables (Vihma et al., 2011), but the modelled humidity inversions were thinnest and weakest under high pressure conditions. Both the observed and modelled humidity inversion strength were controlled by air temperature and specific humidity near the surface and at the $850 \mathrm{hPa}$ level.

\subsubsection{Low-level jets}

A LLJ was identified in $53 \%$ of the observed profiles and $66 \%$ of the modelled profiles. In total, 77 LLJs were found in the observations and 95 in the model results (Table 5). In a few cases, and more commonly in the modelled profiles, there were two wind maxima that fulfilled the criteria. Figure $7(\mathrm{e}, \mathrm{f})$ show the observed and modelled LLJ depth and strength statistics. The average modelled LLJ was deeper and stronger than the average observed LLJ. Observed and modelled LLJ properties did not correlate well. Nevertheless, when a LLJ was present both in the model and observations, most of the LLJ strengths were approximately in the same range $\left(2-5 \mathrm{~m} \mathrm{~s}^{-1}\right)$. The LLJ cores have been commonly found within the temperature inversion layer or at the base of an elevated inversion (Andreas et al., 2000; Tjernström et al., 2004a), but both in our observations and model results the LLJs were typically located above the top of the temperature inversion (Figure 8).

The observed LLJ was strongest under high pressure conditions and a low cloud fraction, and when the air was cold and dry at the temperature inversion top (Vihma et al., 2011). Similarly, the modelled LLJ strength correlated negatively with the near-surface temperature and specific humidity. In addition, the modelled LLJ strength was strongly dependent on the modelled near-surface wind direction. In Isfjorden, the modelled LLJ was clearly strongest when the wind direction was $220^{\circ}$, i.e. the wind was following the slope from Platåberget (Figure 1). In Kongsfjorden, the strongest modelled LLJs occurred when the wind direction was from the north, i.e. wind across the fjord. The observed jet core wind directions and heights suggested that the katabatic winds were the most dominating factor creating LLJs at both fjords. Baroclinity related to the thermal wind between the surface and the $850 \mathrm{hPa}$ level, which could also induce LLJs, did not have detectable impacts on the observed LLJs. In the model, indications of a katabatic flow were often seen at all three sites. In addition to katabatic-induced LLJs, a LLJ was commonly found near the fjord surface; an example is shown in Figure 9. The stronger winds in the middle of the fjord are partly due to channelling and convergence of air masses originating from both sides of the fjord, and partly due to the unstable stratification over the open water, which via enhanced vertical mixing results in wind speed up to $9 \mathrm{~m} \mathrm{~s}^{-1}$ even at the lowest model level. 

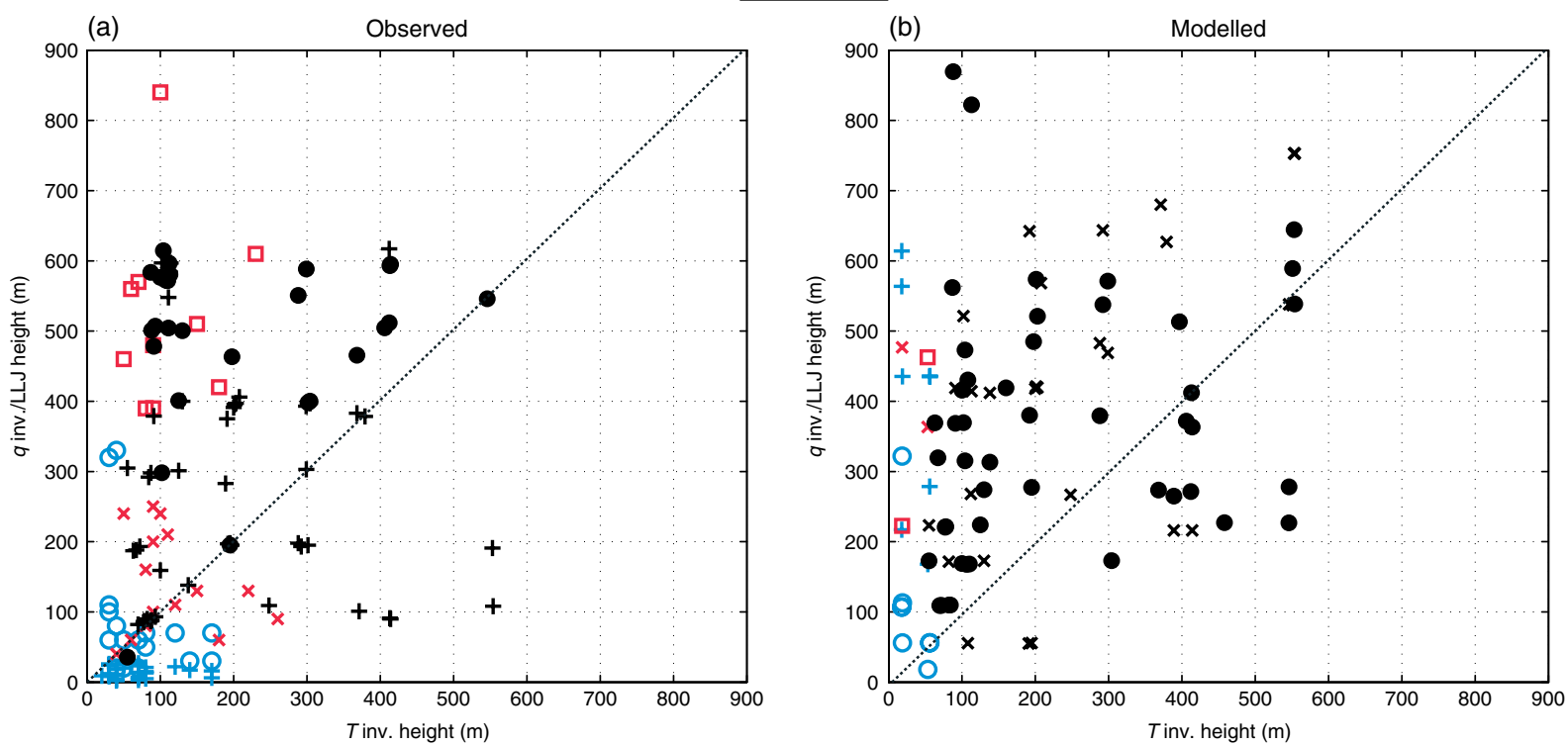

Figure 8. Comparisons of the height of temperature inversion top with the height of humidity inversion top and low-level jet (LLJ) core in (a) the observations and (b) model at Isfjorden site A, Kongsfjorden site B, and Kongsfjorden site C. Only the strongest temperature and humidity inversion and LLJ are shown for each profile. This figure is available in colour online at wileyonlinelibrary.com/journal/qj

(a)

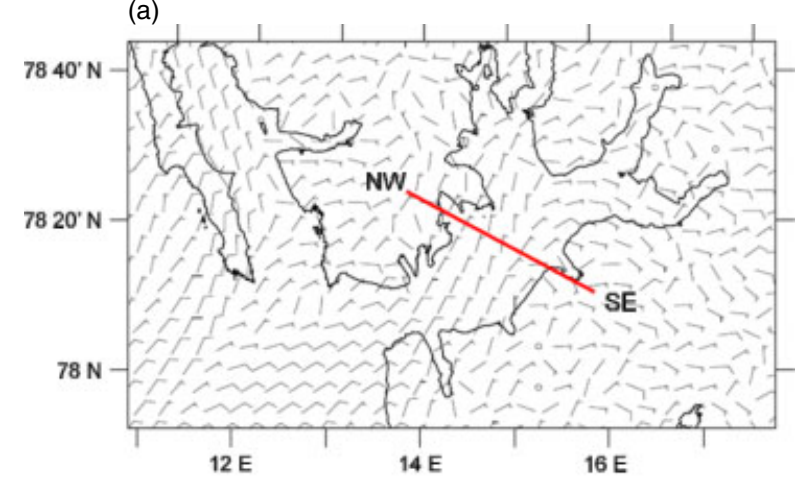

(b)

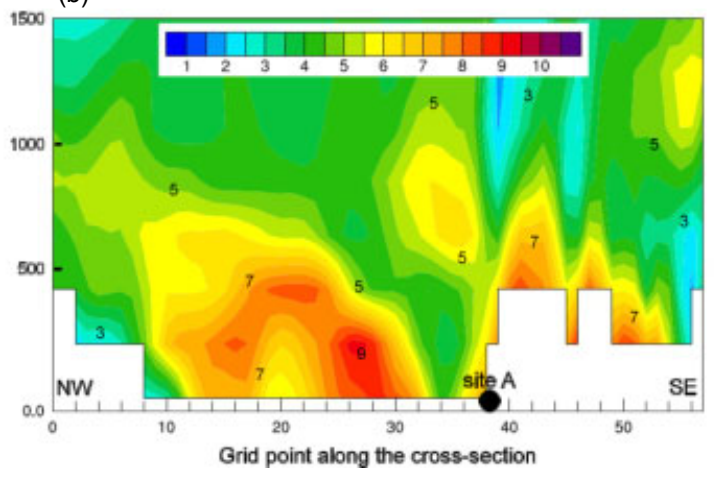

Figure 9. Modelled (a) $10 \mathrm{~m}$ wind barbs and (b) cross-section of the wind speed over Isfjorden at 0400 UTC on 30 March 2009. In (a), a full barb represents a wind speed of $5 \mathrm{~m} \mathrm{~s}^{-1}$. This figure is available in colour online at wileyonlinelibrary.com/journal/qj

\subsubsection{Comparison of vertical profiles over fjords and compact} sea ice

To better understand the effects of fjords, i.e. topography and vicinity of open water, on the ABL, the modelled inversion and LLJ statistics from the two fjords studied were compared with modelled statistics from sea ice east of Svalbard (Figure 1). The location was selected on the basis of three criteria:

(1) minimal topographical influence on the ABL under prevailing northeasterly winds,

(2) compact sea ice cover far from the open sea, and

(3) vicinity of the observation site to minimize the differences in synoptic-scale conditions.

Inversion and LLJ properties were analysed every $6 \mathrm{~h}$ during the whole 16-day simulation period.

Temperature inversions were found in $53 \%$ of the modelled profiles in Isfjorden, $42 \%$ in Kongsfjorden and 95\% over the sea ice. The modelled inversion frequency for the sea ice is close to the estimate of Kahl et al. (1996) for the annual temperature inversion frequency over the Arctic Ocean. Over the fjords, the mean temperature inversion strength was almost $4{ }^{\circ} \mathrm{C}$ lower and the mean depth less than half that over the compact sea ice (Figure 10(a)). Such large differences in the inversion properties were partly caused by the complex topography, which enhances turbulent mixing (Savijärvi, 2009; Kilpeläinen et al., 2011), and partly by the open water on the west side of Svalbard, which is a source of well-mixed air masses. These results are in accordance with the climatological study of Serreze et al. (1992) which illustrated a strong gradient in temperature inversion characteristics in the Norwegian Sea and Svalbard. In our study, the differences in temperature inversion characteristics between the fjords and compact sea ice were as large as typically seen on a spatial scale of $1000 \mathrm{~km}$ or more over the Arctic sea ice.

Also humidity inversions were much more frequent over the compact sea ice than fjords; humidity inversions were identified in $68 \%$ of the modelled profiles in Isfjorden, 


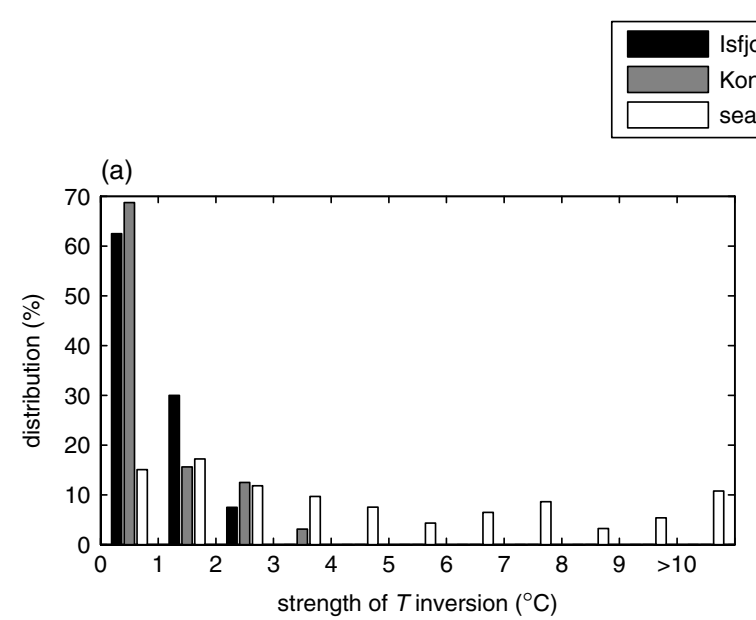

sfjorden (site A)

Kongsfjorden (site C)

sea ice
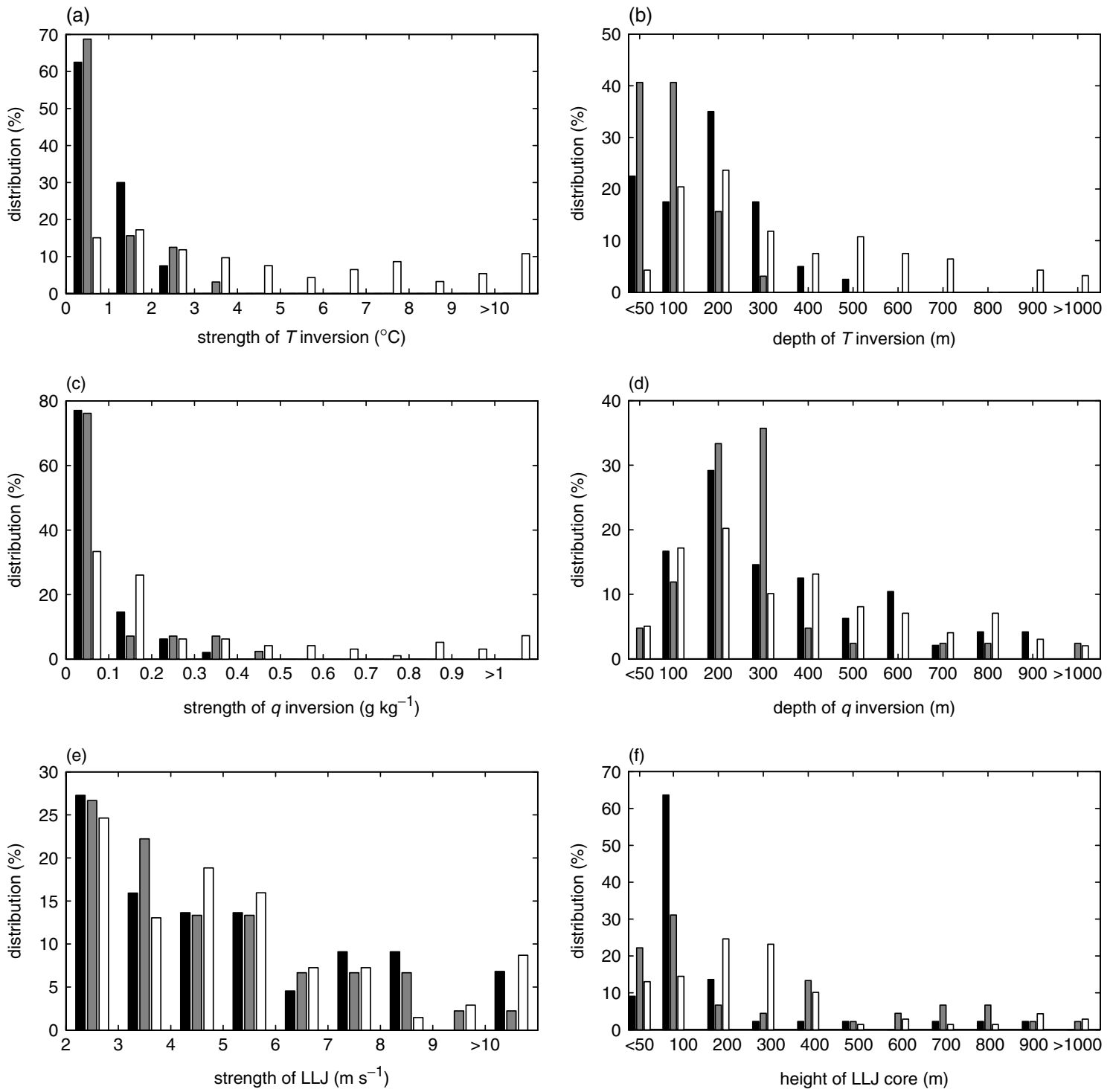

Figure 10. Histograms of modelled (a, b) temperature $T$ inversion, (c, d) humidity $q$ inversion, and (e, f) low-level jet (LLJ) characteristics at Isfjorden, Kongsfjorden and over homogeneous sea ice east of Svalbard.

$55 \%$ in Kongsfjorden and $97 \%$ over sea ice. The depth of the humidity inversion layer over the fjords did not differ notably from the depth over sea ice (Figure 10(d)). The mean strength of the humidity inversion, in turn, was more than three times larger over sea ice and related to strong temperature inversions.

Strong LLJs were found both over the fjords and sea ice (Figure 10(e)). However, the LLJs were less frequent and located at lower altitudes over the fjords than over the compact sea ice. The frequency of occurrence of modelled LLJ was 68\% in Isfjorden, 60\% in Kongsfjorden, and 92\% over sea ice. Over the fjords, the modelled jet core was typically found below a height of $200 \mathrm{~m}$, but over sea ice the core was often at 100-200 m higher altitude (Figure 10(f)).

\section{Conclusions}

Simulated vertical structure of the ABL over Arctic fjords was compared with tethered balloon soundings and mast observations taken in March and April 2009. Comparison of the standard WRF and Polar WRF showed that differences between the performance of these models were marginal. The sensitivity tests indicated that the WRF results were particularly sensitive to snow thermodynamics, which were treated differently in the NOAH and RUC schemes; NOAH outperformed RUC. Of the boundary-layer schemes tested, the QNSE scheme slightly outperformed the MYJ scheme, and the YSU scheme was clearly worse. The performance of QNSE in WRF, which has scarcely been evaluated until this study, was promising and our results encourage further validation.

WRF showed good skill in simulating surface pressure and temporal variations of near-surface temperature and specific humidity. In addition, the temperature profiles were relatively well reproduced above the surface temperature inversions, but temperature inversion strength and depth were notably underestimated by the model. The underestimation was likely a consequence of excessive 
mixing in the $\mathrm{ABL}$ and deficits in the representation of the surface energy balance in the model. It appeared that one of the main challenges of WRF was to capture the humidity inversions. Despite their common occurrence in the observations, WRF captured only a fraction of the humidity inversions and they were too weak and, surprisingly, simultaneously too deep. Further, multiple temperature and humidity inversions were rarely found in the simulated profiles, although they were common in the observations. The modelled frequency and mean strength of LLJs were in fairly good agreement with the observations, although the model tended to overestimate both of them. In addition, model results and observations agreed that LLJs were commonly located above the temperature inversion layer. However, the individual wind speed profiles had relatively large errors which were closely related to significant errors in the modelled LLJ height.

Of the two fjords studied, the results were generally better for Isfjorden, which is larger in area and had less sea ice. Generally, the model errors were largest under high pressure conditions, which indicates that the synoptic situation has a notable impact on the model performance. More local variables, except for wind speed, did not have a significant impact on the model error. Correlation of model bias with modelled variables showed potential for post-processing of the model results.

Compared to the compact sea ice east of Svalbard, modelled temperature and humidity inversions over the fjords were less frequent and remarkably weaker. Also the LLJs were less common and located at lower levels over the fjords. Hence, the vertical structure of the ABL over Svalbard fjords has special characteristics different from those over the compact sea ice. These differences are partly due to vicinity of open water and partly due to the influence of the surrounding topography.

\section{Acknowledgements}

The authors thank Dr D. Bromwich for providing us with the Polar WRF model code and Dr K. M. Hines for his help with the WRF model. The authors are grateful to Dr S. J. Coulson for valuable comments on the manuscript. The fieldwork in Ny-Ålesund, Kongsfjorden, was supported by the European Centre for Arctic Environmental Research (ARCFAC), and the data analyses by the DAMOCLES project (grant 18509) funded by the Sixth Framework Programme of the European Commission.

\section{References}

Andreas EL, Claffey KJ, Makshtas AP. 2000. Low-level atmospheric jets and inversions over the western Weddell Sea. Boundary-Layer Meteorol. 97: 459-486.

Argentini S, Viola AP, Mastrantonio G, Maurizi A, Georgiadis T, Nardino M. 2003. Characteristics of the boundary layer at Ny-Ålesund in the Arctic during the ARTIST field experiment. Ann. Geophys. 46: 185-196.

Atlaskin E, Vihma T. 2012. Evaluation of NWP results for wintertime nocturnal boundary-layer temperatures over Europe and Finland. Q. J. R. Meteorol. Soc. DOI: 10.1002/qj.1885.

Bromwich DH, Hines KM, Bai L-S. 2009. Development and testing of Polar Weather Research and Forecasting model: 2. Arctic Ocean. J. Geophys. Res. 114(D08122): DOI: 10.1029/2008JD010300.

Bromwich DH, Kuo Y-H, Serreze M, Walsh J, Bai LS, Barlage M, Hines K, Slater A. 2010. Arctic System Reanalysis: Call for community involvement. EOS Trans. AGU 91: 13-14.

Brown AR, Beare RJ, Edwards JM, Lock AP, Keogh SJ, Milton SF, Walters DN. 2008. Upgrades to the boundary-layer scheme in the
Met Office numerical weather prediction model. Boundary-Layer Meteorol. 128: 117-132. DOI: 10.1007/s10546-008-9275-0.

Brümmer B, Kirchgssner A, Müller G. 2005. The atmospheric boundary layer over Baltic sea ice. Boundary-Layer Meteorol. 117: 91-109. DOI: 10.1007/s10546-005-0906-4.

Busch N, Ebel U, Kraus H, Schaller E. 1982. The structure of the subpolar inversion-capped ABL. Meteorol. Atmos. Phys. 31: 1-18. DOI: 10.1007./BF02257738.

Cavalieri D, Thorsten M, Comiso J. 2004. AMSR-E/Aqua daily L3 $25 \mathrm{~km}$ brightness temperature and sea ice concentration polar grids V002. National Snow and Ice Data Center: Boulder, Colorado, USA. (digital media).

Chen F, Dudhia J. 2001. Coupling an advanced land surface-hydrology model with the Penn State-NCAR MM5 modeling system. Part I: Model implementation and sensitivity. Mon. Weather Rev. 129: 569-585.

Chou M-D, Suarez MJ. 1994. An efficient thermal infrared radiation parameterization for use in general circulation models. Tech Memo 104606 (3). NASA: Greenbelt, Maryland, USA.

Curry JA, Schramm JL, Rossow WB, Randall D. 1996. Overview of Arctic cloud and radiation characteristics. J. Climate 9: 1731-1764.

Devasthale A, Sedlar J, Tjernström M. 2011. Characteristics of watervapour inversions observed over the Arctic by Atmospheric Infrared Sounder (AIRS) and radiosondes. Atmos. Chem. Phys. 11: DOI: 10.5194/acp-11-9813-2011.

Fogt RL, Bromwich DH. 2008. Atmospheric moisture and cloud cover characteristics forecast by AMPS. Weather Forecasting 23: 914-930. DOI: 10.1175/2008WAF2006100.1.

Grell GA, Devenyi D. 2002. A generalized approach to parameterizing convection combining ensemble and data assimilation techniques. Geophys. Res. Lett. 29: DOI: 10.1029/2002GL015311.

Heinemann G. 2003. Forcing and feedback mechanisms between the katabatic wind and sea ice in the coastal areas of polar ice sheets. $J$. Atmos. Ocean. Sci. 9: 169-201.

Hines KM, Bromwich DH. 2008. Development and testing of Polar Weather Research and Forecasting (WRF) model. Part I: Greenland ice sheet meteorology. Mon. Weather Rev. 136: 1971-1989. DOI: 10.1175/2007MWR2112.1.

Hines KM, Bromwich DH, Bai L-S, Barlage M, Slater AG. 2011. Development and testing of Polar WRF. Part III: Arctic land. J. Climate 24: DOI: 10.1175/2010JCLI3460.1.

Holtslag B. 2006. GEWEX atmospheric boundary-layer study (GABLS) on stable boundary layer. Boundary-Layer Meteorol. 118: 243-246. DOI: $10.1007 / \mathrm{s} 10546-005-9008-6$.

Hong S-Y, Dudhia J, Chen S-H. 2004. A revised approach to ice microphysical processes for the bulk parameterization of clouds and precipitation. Mon. Weather Rev. 132: 103-120.

Hong S-Y, Noh Y, Dudhia J. 2006. A new vertical diffusion package with an explicit treatment of entrainment processes. Mon. Weather Rev. 134: 2318-2341.

Hunt JCR, Shutts GJ, Derbyshire SH. 1996. Stably stratified flows in meteorology. Dyn. Atmos. Oceans 23: 63-79.

Janjić ZI. 1996. The surface layer in the NCEP Eta model. In Proceedings of Eleventh conference on numerical weather prediction, Norfolk, VA, 19-23 August 1996. Amer. Meteorol. Soc: Boston. 354-355.

Janjić ZI. 2002. 'Non-singular implementation of the Mellor-Yamada level 2.5 scheme in the NCEP Meso model'. NCEP Office Note 437. http://www.emc.ncep.noaa.gov/officenotes/fullTOC.html

Jung T, Balsamo G, Bechtold P, Beljaars ACM, Köhler M, Miller MJ, Morcrette J-J, Orr A, Rodwell MJ, Tompkins AM. 2010. The ECMWF model climate: recent progress through improved physical parametrizations. Q. J. R. Meteorol. Soc. 136: 1145-1160. DOI: 10.1002/qj.634.

Kahl JDW, Martinez DA, Zaitseva NA. 1996. Long-term variability in the low-level inversion layer over the Arctic Ocean. Int. J. Climatol. 16: $1297-1313$.

Kilpeläinen T, Sjöblom A. 2010. Momentum and sensible heat exchange in an ice-free Arctic fjord. Boundary-Layer Meteorol. 134: 109-130. DOI: $10.1007 / \mathrm{s} 10546-009-9435-\mathrm{x}$.

Kilpeläinen T, Vihma T, Olafsson H. 2011. Modelling of spatial variability and topographic effects over Arctic fjords in Svalbard. Tellus 63A: 223-237. DOI: 10.1111/j.1600-0870.2010.00481.x.

Lammert A, Brümmer B, Haller M, Müller G, Schyberg H. 2010. Comparison of three weather prediction models with buoy and aircraft measurements under cyclone conditions in Fram Strait. Tellus 62A: 361-376. DOI: 10.1111/j.1600-0870.2010.00460.x.

Lüpkes C, Vihma T, Birnbaum G, Wacker U. 2008. Influence of leads in sea ice on the temperature of the atmospheric boundary 
layer during polar night. Geophys. Res. Lett. 35: (L03805). DOI: 10.1029/2007GL032461.

Lüpkes C, Vihma T, Jakobson E, König-Langlo G, Tetzlaff A. 2010. Meteorological observations from ship cruises during summer to the central Arctic: A comparison with reanalysis data. Geophys. Res. Lett. 37: L09810 DOI: 10.1029/2010GL042724.

Mäkiranta E, Vihma T, Sjöblom A, Tastula E-M. 2011. Observation and modelling of the atmospheric boundary layer over sea ice in a Svalbard fjord. Boundary-Layer Meteorol. 140: 105-123. DOI: 10.1007/s10546-011-9609-1.

Mlawer EJ, Taubman SJ, Brown PD, Iacono MJ, Clough SA. 1997. Radiative transfer for inhomogeneous atmospheres: RRTM, a validated correlated-k model for the longwave. J. Geophys. Res. 102: 16663-16682. DOI: 10.1029/97JD00237.

Mölders N, Kramm G. 2010. A case study on wintertime inversions in interior Alaska with WRF. Atmos. Res. 95: 314-332. DOI: 10.1016/j.atmosres.2009.06.002.

Poulos GS, Burns SP. 2003. An evaluation of bulk Ri-based surface layer flux formulas for stable and very stable conditions with intermittent turbulence. J. Atmos. Sci. 60: 2523-2537.

Renfrew IA, Anderson PS. 2006. Profiles of katabatic flow in summer and winter over Coats Land, Antarctica. Q. J. R. Meteorol. Soc. 132 $779-802$.

Rinke A, Dethloff K, Cassano JJ, Christensen JH, Curry JA, Du P, Girard E, Haugen J-E, Jacob D, Jones CG, Kltzow M, Laprise R, Lynch AH, Pfeifer S, Serreze MC, Shaw MJ, Tjernström M, Wyser K, Zagar M. 2006. Evaluation of an ensemble of Arctic regional climate models: spatiotemporal fields during the SHEBA year. Clim. Dyn. 26: 459-472. DOI: 10.1007/s00382-005-0095-3

Savijärvi H. 2009. Stable boundary layer: Parametrizations for local and larger scales. Q. J. R. Meteorol. Soc. 135: 914-921.

Sedlar J, Tjernström M. 2009. Stratiform cloud-inversion characterization during the Arctic melt season. Boundary-Layer Meteorol. 132: 455-474. DOI: 10.1007/s10546-009-9407-1.

Serreze MC, Barry RG. 2005. The Arctic climate system. Cambridge University Press: Cambridge, UK.

Serreze MC, Kahl JD, Schnell RC. 1992. Low-level temperature inversions of the Eurasian Arctic and comparisons with Soviet drifting station data. J. Clim. 5: 615-629.

Serreze MC, Barry RG, Walsh JE. 1995. Atmospheric water vapor characteristics at $70^{\circ}$ N. J. Clim. 8: 719-731.

Skamarock WC, Klemp JB, Dudhia J, Gill DO, Barker DM, Duda MG Huang X-Y, Wang W, Powers JG. 2008. A description of the Advanced Research WRF version 3. Technical Note 475+STR. NCAR: Boulder, Colorado, USA.

Slater AG, Schlosser CA, Desborough CE, Pitman AJ, HendersonSellers A, Robock A, Vinnikov KY, Boone A, Braden H, Chen F, Cox PM, De Rosnay P, Dickinson RE, Dai Y-J, Duan Q, Entin J, Etchevers P, Gedney N, Gusev YM, Habets F, Kim J, Koren V, Kowalczyk A, Nasonova ON, Noilhan J, Schaake S, Shmakin AB,
Smirnova TG, Verseghy D, Wetzel P, Xue Y, Yang ZL, Zeng Q. 2001. The representation of snow in land surface schemes: results from PILPS 2(d). J. Hydrometeorol. 2: 7-25.

Storm B, Dudhia J, Basu S, Swift A, Giammanco I. 2008. Evaluation of the Weather Research and Forecasting model on forecasting low-level jets: implications for wind energy. Wind Energy DOI:10.1002/we.288.

Stull RB. 1988. An introduction to boundary-layer meteorology. Kluwer Academic Publishers: Dordrecht, The Netherlands.

Sukoriansky S, Galperin B. 2008. Anisotropic turbulence and internal waves in stably stratified flows (QNSE theory). Phys. Scripta 014036. DOI: 10.1088/0031-8949/2008/T132/014036.

Sukoriansky S, Galperin B, Perov V. 2006. A quasi-normal scale elimination model of turbulence and its application to stably stratified flows. Nonlin. Proc. Geophys. 13: 9-22.

Svensson G, Holtslag AAM, Kumar V, Mauritsen T, Steeneveld GJ, Angevine WM, Bazile E, Beljaars A, de Bruijn EIF, Cheng A, Conangla L, Cuxart J, Ek M, Fanlk MJ, Freedman F, Kitagawa H, Larson VE, Lock A, Mailhot J, Masson V, Park S, Pleim J, Soderberg S, Weng W, Zampieri M. 2011. Evaluation of the diurnal cycle in the atmospheric boundary layer over land as represented by a variety of single-column models: the second GABLS experiment. BoundaryLayer Meteorol. 140: 177-206. DOI: 10.1007/s10546-011-9611-7.

Tastula E-M, Vihma T. 2011. WRF model experiments on the Antarctic atmosphere in winter. Mon. Weather Rev. 139: 1279-1291. DOI: 10.1175/2010MWR3478.1.

Tjernström M, Graversen RG. 2009. The vertical structure of the lower Arctic troposphere analysed from observations and the ERA-40 reanalysis. Q. J. R. Meteorol. Soc. 135: 431-443. DOI: 10.1002/qj.380.

Tjernström M, Leck C, Persson POG, Jensen ML, Oncley SP, Targino A. 2004a. The summertime Arctic atmosphere: meteorological measurements during the Arctic Ocean Experiment 2001. Bull. Am. Meteorol. Soc. DOI: 10.1175/BAMS-85-9-1305.

Tjernström M, Žagar M, Svensson G, Cassano JJ, Pfeifer S, Rinke A, Wyser K, Dethloff K, Jones C, Semmler T, Shaw M. 2004b. Modelling the Arctic boundary layer: an evaluation of six ARCMIP regionalscale models using data from the SHEBA project. Boundary-Layer Meteorol. 117: 337-381. DOI: 10.1007/s10546-004-7954-z.

Valkonen T, Vihma T, Doble M. 2008. Mesoscale modeling of the atmosphere over Antarctic sea ice: a late-autumn case study. Mon. Weather Rev. 136: 1457-1474. DOI: 10.1175/2007MWR2242.1.

Vihma T, Uotila J, Launiainen J. 1998. Air-sea interaction over a thermal marine front in the Denmark Strait. J. Geophys. Res. 103: 27665-27678. DOI: 10.1029/98JC02415.

Vihma T, Hartmann J, Lüpkes C. 2003. A case study of an on-ice air flow over the Arctic marginal sea-ice zone. Boundary-Layer Meteorol. 107: 189-217. DOI: 10.1023/A:1021599601948.

Vihma T, Kilpeläinen T, Manninen M, Sjöblom A, Jakobson E, Palo T, Jaagus J, Maturilli M. 2011. Characteristics of temperature and humidity inversions and low-level jets over Svalbard fjords in spring. Adv. Meteorol. DOI: 10.1155/2011/486807. 